\title{
WestVirginiaUniversity
}

THE RESEARCH REPOSITORY @ WVU

Graduate Theses, Dissertations, and Problem Reports

2007

\section{Essays on the effects of the voter initiative in U.S. states}

Gregory M. Randolph

West Virginia University

Follow this and additional works at: https://researchrepository.wvu.edu/etd

\section{Recommended Citation}

Randolph, Gregory M., "Essays on the effects of the voter initiative in U.S. states" (2007). Graduate

Theses, Dissertations, and Problem Reports. 4329.

https://researchrepository.wvu.edu/etd/4329

This Dissertation is protected by copyright and/or related rights. It has been brought to you by the The Research Repository @ WVU with permission from the rights-holder(s). You are free to use this Dissertation in any way that is permitted by the copyright and related rights legislation that applies to your use. For other uses you must obtain permission from the rights-holder(s) directly, unless additional rights are indicated by a Creative Commons license in the record and/ or on the work itself. This Dissertation has been accepted for inclusion in WVU Graduate Theses, Dissertations, and Problem Reports collection by an authorized administrator of The Research Repository @ WVU.

For more information, please contact researchrepository@mail.wvu.edu. 


\title{
Essays on the Effects of the Voter Initiative in U.S. States
}

\section{Gregory M. Randolph}

\author{
Dissertation Submitted to the \\ College of Business and Economics at \\ West Virginia University \\ in partial fulfillment of the requirements for the degree of
}

\author{
Doctor of Philosophy \\ in \\ Economics
}

\author{
Russell S. Sobel, Ph.D., Chair \\ Stratford M. Douglas, Ph.D. \\ George W. Hammond, Ph.D. \\ Peter T. Leeson, Ph.D. \\ Santiago M. Pinto, Ph.D.
}

Department of Economics

Morgantown, West Virginia

2007

Keywords: Voter Initiative, Direct Democracy

Copyright @ 2007 Gregory M. Randolph 


\section{Abstract \\ Essays on the Effects of the Voter Initiative in U.S. States}

\section{Gregory M. Randolph}

This dissertation is a collection of papers that examines the effects of the voter initiative in U.S. states. Chapter 1 provides a brief introduction to the voter initiative process and outlines the research agenda for this dissertation. Chapter 2 explores the history of the voter initiative in U.S. states and examines the differences in the voter initiative process between states in the U.S. Additionally, this chapter provides a general survey of the literature regarding the effects of the voter initiative on political and economic outcomes. Chapter 3 examines the interest group orientation of total state spending in U.S. states. A measure for the publicness of state spending is calculated in order to examine the interest group influence on state spending in both voter initiative and non-initiative states. The results show that the voter initiative process does not decrease the interest group orientation of state expenditures. Chapter 4 investigates the impact of the voter initiative on total per capita state election cycle spending in state gubernatorial and state legislative elections. The results indicate that the availability of the voter initiative decreases the value of both state legislative and state gubernatorial offices. The impact of the voter initiative appears to have a larger negative effect on the value of state legislative offices in comparison to state gubernatorial offices. Chapter 5 empirically analyzes the impact of the voter initiative on the production of legislation in U.S. states. The amount of legislation enacted by state legislators is estimated in order to examine the effects of the voter initiative. This chapter also explores the impact of the voter initiative on the number of special sessions called in U.S. states. Finally, the effect of the voter initiative on the usage of the governor's veto in U.S. states is examined. The results indicate that voter initiative states enact more legislation, call a greater number of special sessions, and have less gubernatorial vetoes than non-initiative states. Chapter 6 summarizes the

major findings in the dissertation, discusses the policy implications, and suggests future areas of research regarding the voter initiative. 


\section{Acknowledgements}

I would like to thank Dr. Russell Sobel for his tremendous contribution toward the completion of my dissertation and his continuous support during my time at WVU. I would also like to thank all of the WVU faculty, staff, and graduate students who have helped throughout my graduate school career. This would not have been possible without all of you.

I would also like to thank all of my friends and family members for being there for me through the years. In particular, I would like to thank my parents for their continuous support and all of the sacrifices that they have made in order to provide me with the opportunity to complete my education. 


\section{TABLE OF CONTENTS}

Notice of copyright ........................................................................................................................... i

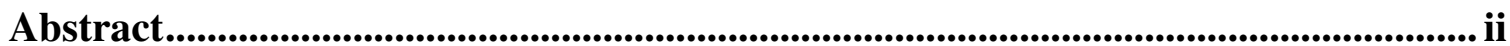

Acknowledgements ............................................................................................................ii

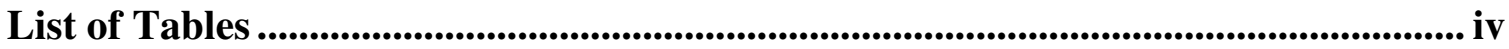

List of Figures............................................................................................................................................ v

Chapter 1: The Effects of the Voter Initiative in U.S. States

Section 1.1: Introduction .................................................................................. 1

Section 1.2: Dissertation Research Agenda............................................................. 2

\section{Chapter 2: The Voter Initiative}

Section 2.1: The History of the Voter Initiative in U.S. States ................................... 9

Section 2.2: Differences in the Voter Initiative Process in U.S. States .......................... 10

Section 2.3: Usage of the Voter Initiative in U.S. States............................................ 12

Section 2.4: Important Issues in the Voter Initiative Literature ..................................... 14

Chapter 3: Do Voter Initiatives Affect the Interest Group Orientation of Government Spending?

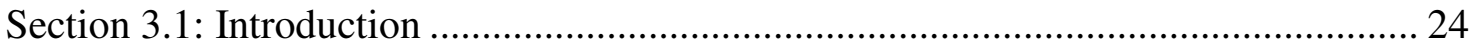

Section 3.2: Does the Voter Initiative Favor the Median Voter? .................................. 26

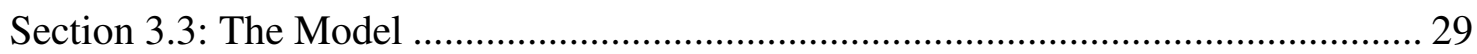

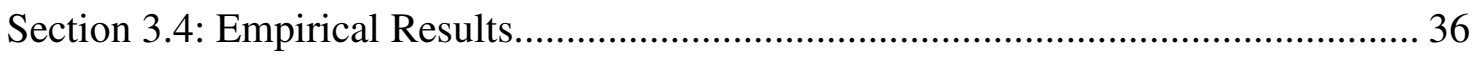

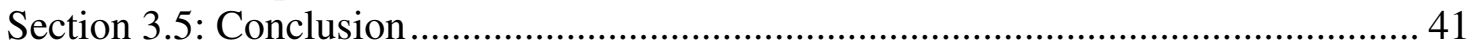

Chapter 4: The Effect of the Voter Initiative on the Value of State Governmental Offices: Evidence from State Legislative and Gubernatorial Elections

Section 4.1: Introduction ........................................................................................... 43

Section 4.2: The Effect of the Voter Initiative on Relative Power............................... 45

Section 4.3: State Legislative Election Cycle Spending.............................................. 49

Section 4.4: State Legislative Gubernatorial Cycle Spending........................................ 54

Section 4.5: Comparison of the Legislative Branch and the Executive Branch............ 58

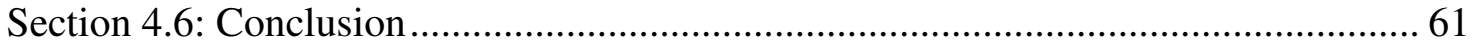

Chapter 5: Measuring the Indirect Effect: Voter Initiatives and Legislative Production in U.S. States

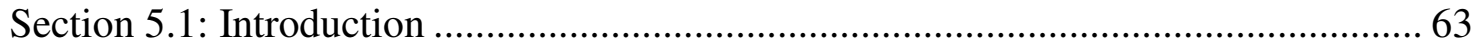

Section 5.2: The Indirect Effect of the Voter Initiative ................................................ 65 


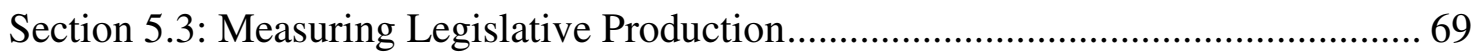

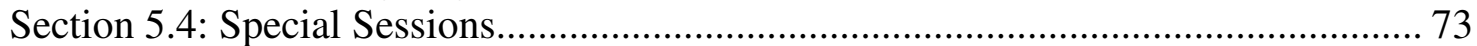

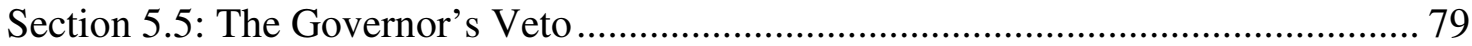

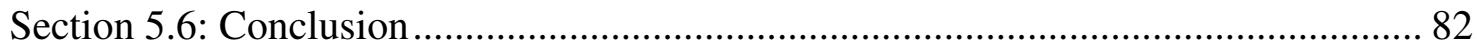

\section{Chapter 6: Summary and Conclusion}

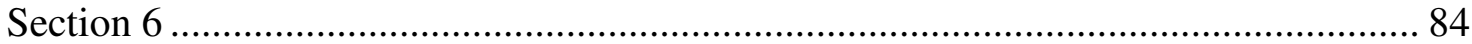

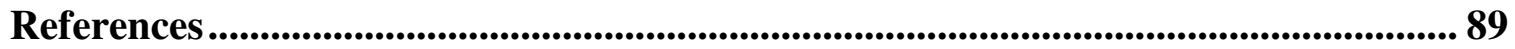

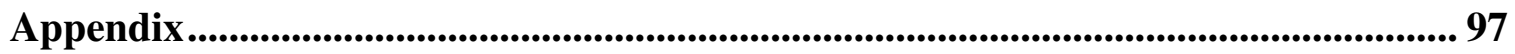




\section{List of Tables}

\section{Chapter 1: The Effects of the Voter Initiative in U.S. States}

Table 1.1: The Voter Initiative State Differences....................................................... 13

Chapter 3: Do Voter Initiatives Affect the Interest Group Orientation of Government Spending?

Table 3.1: Total State Government Expenditure Estimates

Table 3.2: Monte Carlo Point Estimates.

Chapter 4: The Effect of the Voter Initiative on the Value of State Governmental Offices: Evidence from State Legislative and Gubernatorial Elections

Table 4.1: Descriptive Statistics for Legislative Spending Regression....................... 53

Table 4.2: Total State District Legislator Election Cycle Spending Per Capita............ 54

Table 4.3: Descriptive Statistics for Gubernatorial Spending Regressions ................... 58

Table 4.4: Total Election Cycle Gubernatorial Spending Per Capita.......................... 59

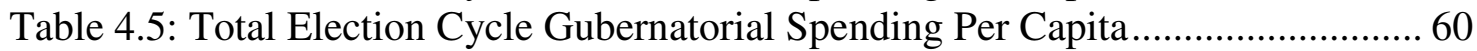

Chapter 5: Measuring the Indirect Effect: Voter Initiatives and Legislative Production in U.S. States

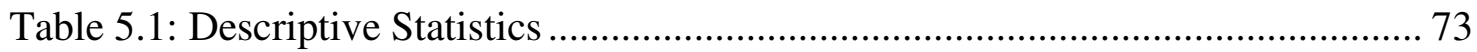

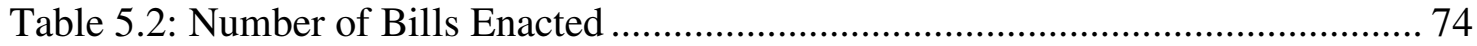

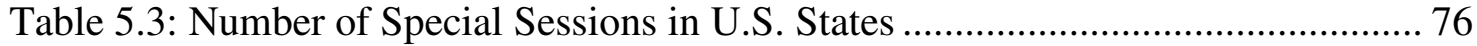

Table 5.4: Gubernatorial Vetoes in U.S. States ........................................................ 81 


\section{List of Figures}

\section{Chapter 2: The Voter Initiative}

Figure 2.1: U.S. States with the Voter Initiative Process .......................................... 11

Figure 2.2: Number of Voter Initiatives Proposed and Passed by Decade................... 15

\section{Chapter 3: Do Voter Initiatives Affect the Interest Group Orientation of Government} Spending?

Figure 3.1: Publicness Measure.

Chapter 4: The Effect of the Voter Initiative on the Value of State Governmental Offices: Evidence from State Legislative and Gubernatorial Elections

Figure 4.1: The Effect of the Voter Initiative on the Relative Power of the Legislative Branch, the Executive Branch, and the Median Voter. 


\section{Chapter 1}

\section{The Effects of the Voter Initiative in U.S. States}

\subsection{Introduction}

The voter initiative is a form of direct democracy that allows groups and individual voters to propose statutes or constitutional amendments. In states where the voter initiative is available, individuals can place laws or amendments on the ballot, allowing voters to directly decide the outcome. In order to place a voter initiative on the ballot, a certain number of signatures must be collected to provide evidence of sufficient support for the measure. The signature requirement varies across states in which the voter initiative is available. Once the signature requirement is met, the policy proposal will appear on the ballot. The proposal is adopted if a majority of voters vote in favor of the proposal.

The resurgence of the voter initiative in the late 1970's and its continuously increasing usage has attracted scholarly attention in recent years. The primary question surrounding the voter initiative involves identifying the true beneficiaries of the voter initiative process. Opponents of the voter initiative believe that the voter initiative process is subverted by narrow special interest groups. They cite the massive amounts of money that are involved in voter initiatives as evidence. These opponents claim that special interest groups can motivate supporters while ordinary voters have little incentive to vote. They allege that individuals lack knowledge of the issues and can be lead astray by special interest groups. Additionally, they argue that the behavior of the legislature can be distorted by the threat of a voter initiative. Due to the aforementioned reasons, opponents of the voter initiative claim that the voter initiative harms the median voter. Conversely, proponents of the voter initiative process assert that the 
voter initiative process gives the general public a method by which they can directly affect policies that may otherwise cater to special interests. Additionally, proponents claim that the threat of a voter initiative may cause the legislature to enact legislation that is better aligned with the preferences of the median voter (Matsusaka, 2005a).

While the majority of the voter initiative research is concentrated in attempting to determine the primary beneficiaries of the process, other recent research has attempted to examine the impact of the voter initiative on numerous other areas. The issue of voter competence and the role of money in the voter initiative process have received a great deal of attention in recent years. Other recent research has focused on the effects of the voter initiative on the political process and policy outcomes.

\subsection{Dissertation Research Agenda}

Chapter 2 chronicles the history of the voter initiative in U.S. states, examines differences in the voter initiative process between states, explores the usage of the voter initiative, and reviews the important existing voter initiative literature. While the usage of the voter initiative is often viewed as a recent phenomenon, the voter initiative was first introduced at the state level in South Dakota in 1898. The majority of states with the voter initiative adopted the process in the following twenty years. Currently, 24 states have some form of the voter initiative. However, the there are several important differences among the voter initiative states that have a significant impact on the usage of the voter initiative.

As mentioned previously, interest in the effects of the voter initiative has increased dramatically in the past few decades as use of the voter initiative has grown rapidly. While there are many areas left unexplored, scholars have focused their attention on several key issues. The 
investigation into the theory behind the voter initiative involves examining agency problems, the unbundling of logrolling, and the quality of information. The issues of voter competence, the role of money in the voter initiative process, and the possible tyranny of the majority are often evaluated as well. Finally, some of the most crucial research focuses on the effects of the voter initiative on policy outcomes and the performance of government.

One of the most important and heavily debated issues involving the voter initiative is the determination of the primary beneficiaries of the voter initiative process. While subjective observations have been the basis of the argument in the past, recent empirical observations have suggested that the median voter is the primary beneficiary. The most compelling evidence is provided by Matsusaka (2004), who examines state and local spending and taxation throughout the twenty-first century. He finds that states in which the voter initiative is available tend to have lower taxes and spending levels, rely more on user fees as opposed to general taxes, and spend more at the local government level and less at the state government level in comparison to states in which the voter initiative process is unavailable. Additionally, he examines opinion surveys and finds that a large majority of U.S. citizens support these causes. Evidence also suggests that policies that are enacted in voter initiative states are favored by the median voter. Gerber (1999) finds that the death penalty and parental notification of abortions in minors are more prevalent in voter initiative states in comparison to states that lack the voter initiative process. These issues are largely preferred by the majority in opinion surveys. Matsusaka (2004) also finds that voter initiative states are more likely to have term limits for legislators, which is also supported by a majority of voters in opinion surveys.

However, the issue of the influence of special interest groups over the voter initiative process remains at the center of the voter initiative debate. In order to examine this issue, 
Chapter 3 investigates the interest group influence on total state government expenditures. State expenditures that are allocated due to special interest influence are a private good because the benefits accrue directly to members of the interest group. For example, more money must be allocated in order to provide an additional farm subsidy in a state. In contrast, public goods are non-rival in consumption and non-excludable. For instance, an additional individual can share in the use of an uncongested rural highway at virtually no additional cost. While we would expect a significant amount of total state government expenditures to be a private good, we do expect some degree of public expenditures as well. This chapter examines the publicness of total state spending and compares states in which the voter initiative process is available and states that lack the voter initiative process. Because interest group influenced spending is a private good, a greater level of private spending would suggest a higher interest group influence on total state government spending.

Following the examples of Deno and Mehay (1987), Holcombe and Sobel (1995), and King (2006), this chapter employs the empirical median voter model to estimate the 'publicness' of total state spending. The model estimates the demand for total state spending. An estimate of the degree to which total state government spending is a private good (on a scale of $0 \%$ to $100 \%$ ) is obtained and the results for voter initiative states and states in which the voter initiative process is unavailable are compared. The results suggest that total state government spending is not significantly more public in voter initiative states. At the very least, we are able to reject the notion that special interest groups exert less influence over total state spending in voter initiative states. Boehmke $(2002,2005)$ provides a plausible explanation for this finding. He finds that states that have the initiative process available have a higher number of interest groups in comparison to states that lack the voter initiative process. 
While much of the voter initiative literature focuses on whether the voter initiative shifts power toward special interest groups or the median voter, the relative power shift between the legislature, the executive branch, and the median voter receives little attention. When the voter initiative is unavailable, the legislature has monopoly control over law making. However, when the voter initiative is available, the median voter and the governor play a much larger role in the process.

Matsusaka (2005c) examines the issue of the relative shift in power when the voter initiative process is available. From the governor's perspective, the availability of the voter initiative can be helpful or harmful depending on the preferences of the median voter on a given issue. If the preferences of the median voter are closer to the preferences of the governor than the preferences of the legislature, the voter initiative can serve as a useful policy tool for the governor. The governor can support a voter initiative and change policy through the passage of a voter initiative (the direct effect of the voter initiative) or proactive legislative activity (the indirect effect of the voter initiative). However, if the preferences of the median voter are more closely aligned with the preferences of the legislature than the preferences of the governor, the voter initiative process may take power away from the governor. A voter initiative may result in a policy that is less favorable to the governor. Therefore we can conclude that the effect of the voter initiative on the power of the governor is ambiguous in theory. However, the voter initiative appears to decrease the power of the legislature under all circumstances in theory. Finally, the voter initiative can benefit the median voter and should not harm the median voter under any conditions at the very least.

In order to examine these theories, Chapter 4 estimates the value of both state legislative and state gubernatorial office seats. Because candidates and their donors are well aware of the 
resources that they will potentially control and the decision-making power that they will have, we can expect that candidates and donors will spend an amount comparable to the value of the resources and power in order to obtain control of them. After controlling for other factors, this chapter examines the effect of the voter initiative on the value of office.

Total per capita election cycle spending for all state legislative open seats is estimated for the year 2000 following an empirical specification by Hogan $(1999,2000)$. The estimates show that the availability of the voter initiative process significantly decreases campaign spending in state legislative elections. Following Lott (2000), total per capita spending in state gubernatorial election cycle campaigns is estimated for all state gubernatorial elections from 1980 to 2002. The results suggest that the voter initiative also has a significantly negative effect on gubernatorial campaign spending as well. Finally, the average percentage decrease in campaign spending due to the voter initiative process is calculated for both state legislative and gubernatorial elections. The voter initiative process appears to cause a larger percentage decrease in spending in state legislative campaigns when compared to state gubernatorial campaigns.

Chapter 5 examines the effect of the voter initiative on legislative production. There are two avenues by which the voter initiative can help shape policy outcomes. The first means of influencing policy occurs through the passage of a voter initiative that is placed on the ballot and approved by the voters. This is known as the direct effect of the voter initiative. The voter initiative can also cause the legislature to proactively enact legislation in order to avoid the passage of a voter initiative that the legislature views as unfavorable. While the voter initiative literature tends to focus on the direct effect, scholars often believe that the indirect effect of the voter initiative may be of equal or greater importance. 
Gerber (1996) and Gerber and Hug (2001) provide the theory behind the indirect effect of the voter initiative. While the passage of voter initiatives on the ballot are relatively easy to measure, the indirect effect of the voter initiative is much more difficult to capture. The indirect effects of the voter initiative are simply categorized as legislation and it is difficult to separate the indirect effects from other legislation. In order to examine this aspect of the voter initiative, this chapter employs an empirical specification following Rogers (2005). The number of bills enacted during the regular legislative session by states from 1981 - 2001 (every other year due to the available data in the Book of the States) is estimated. The results suggest that the legislature enacts more legislation in states where the voter initiative is available, implying that the indirect effect of the voter initiative does have a significant impact on legislative behavior.

The number of special sessions called by U.S. states from $1981-2001$ is also examined in this chapter. States can call special sessions in order to deal with a number of important issues. An estimation of the number of special sessions called in U.S. states shows that the voter initiative has a significantly positive effect on the number of special sessions called. This implies once again that the voter initiative does impact the operation of the state legislature.

Finally this chapter examines the usage of the governor's veto over the same time period. State governors in forty-nine U.S. states enjoy some type of veto power over the legislature. In theory, there is reason to suspect that the governor will not increase usage of the veto when the voter initiative is available. Matsusaka (2005c) explains that the preferences of the state governor are generally aligned with the preferences of the state median voter because the governor is elected in a statewide election. Additionally, voter initiatives are not subject to the governor's veto. Therefore, if the state legislature passes bills in order to avoid a possible voter initiative, the governor may be unlikely to veto the legislation even if the legislation is not 
aligned with the governors preferences because the voters could enact the policy through a voter initiative anyways. The number of gubernatorial vetoes exercised from $1981-2001$ during the regular legislative session is estimated. The availability of the voter initiative has a significantly negative impact on the number of gubernatorial vetoes.

Chapter 6 of the dissertation will summarize the major findings of the each of the research chapters and discuss the relevant policy implications. Future areas of research will also be discussed given the current literature and the contributions of this dissertation. 


\section{Chapter 2}

\section{The Voter Initiative}

\subsection{The History of the Voter Initiative in U.S. States}

The concept of direct democracy in the U.S. can be traced back to New England in the 1600's. ${ }^{1}$ The referendum process was born through the town hall meetings that were used in order to determine policies for the town at the time. The referendum process was adopted by several states in the late $18^{\text {th }}$ and early $19^{\text {th }}$ century. In 1857 , the federal government required all new states that entered the union to provide the legislative referendum process for state constitutional amendments. However the voter initiative process, the direct democracy counterpart to the referendum, did not gain popularity until late in the $19^{\text {th }}$ century (Initiative and Referendum Institute).

The voter initiative began to gain popularity in the U.S. around 1885 when Father Robert Haire, a South Dakota priest, and Benjamin Urner, a New Jersey publisher, began to lobby for the provision of the referendum and voter initiative process in U.S. states. ${ }^{2}$ The populist and progressive movements were established and became quite popular over the next two decades. Supporters of the parties had become disillusioned with the government due to constant catering to special interest groups. The parties supported a number of governmental reforms, including the voter initiative process (Initiative and Referendum Institute). They viewed the voter initiative as the primary tool by which they could influence policy in the presence of a legislature that was subverted to special interests. Nebraska became the first state to allow local

\footnotetext{
${ }^{1}$ All dates, data, and information in this section, unless noted otherwise, can be found in Citizen Lawmakers by Schmidt (1991) and "A Brief History of the Initiative and Referendum Process in the United States" by the Initiative and Referendum Institute.

${ }^{2}$ Information found in "The Initiative and Referendum Timeline" by the Initiative and Referendum Institute.
} 
governments to use the voter initiative and popular referendum in 1897. South Dakota became the first state to adopt the voter initiative and referendum process at the state level the following year.

By 1918, 20 states had adopted a form of the voter initiative process. However, legislators in other states resorted to numerous tactics to discourage the voter initiative process. Several state legislators ignored advisory referenda that were approved by the voters. In the case of Texas, legislators gave voters the option to adopt the voter initiative process with a $20 \%$ signature requirement, much higher than other states. Voters rejected the process because it would be unusable with such a high signature requirement (Initiative and Referendum Institute). Evidence suggests that some southern and eastern U.S. states did not embrace the voter initiative because of a fear that immigrants and African Americans would be able to affect policy outcomes (Schmidt, 1991).

For over forty years, the voter initiative process was not adopted by any U.S. states. Decades after the flurry of voter initiative ratification, Alaska included the voter initiative process in their state constitution when they were admitted as a state in 1959. Three states have adopted the voter initiative process since Alaska, with Mississippi being the most recent state in 1992. The total number of states in which the voter initiative process is available currently stands at 24 states. The majority of these voter initiative states are located in the west. Figure 2.1 displays the locations of the voter initiative states throughout the U.S. However, the voter initiative is represented in every region throughout the U.S. Additionally, numerous states allow the voter initiative process at the local government level.

\subsection{Differences in the Voter Initiative Process in U.S. States}


Figure 2.1: U.S. States with the Voter Initiative Process .

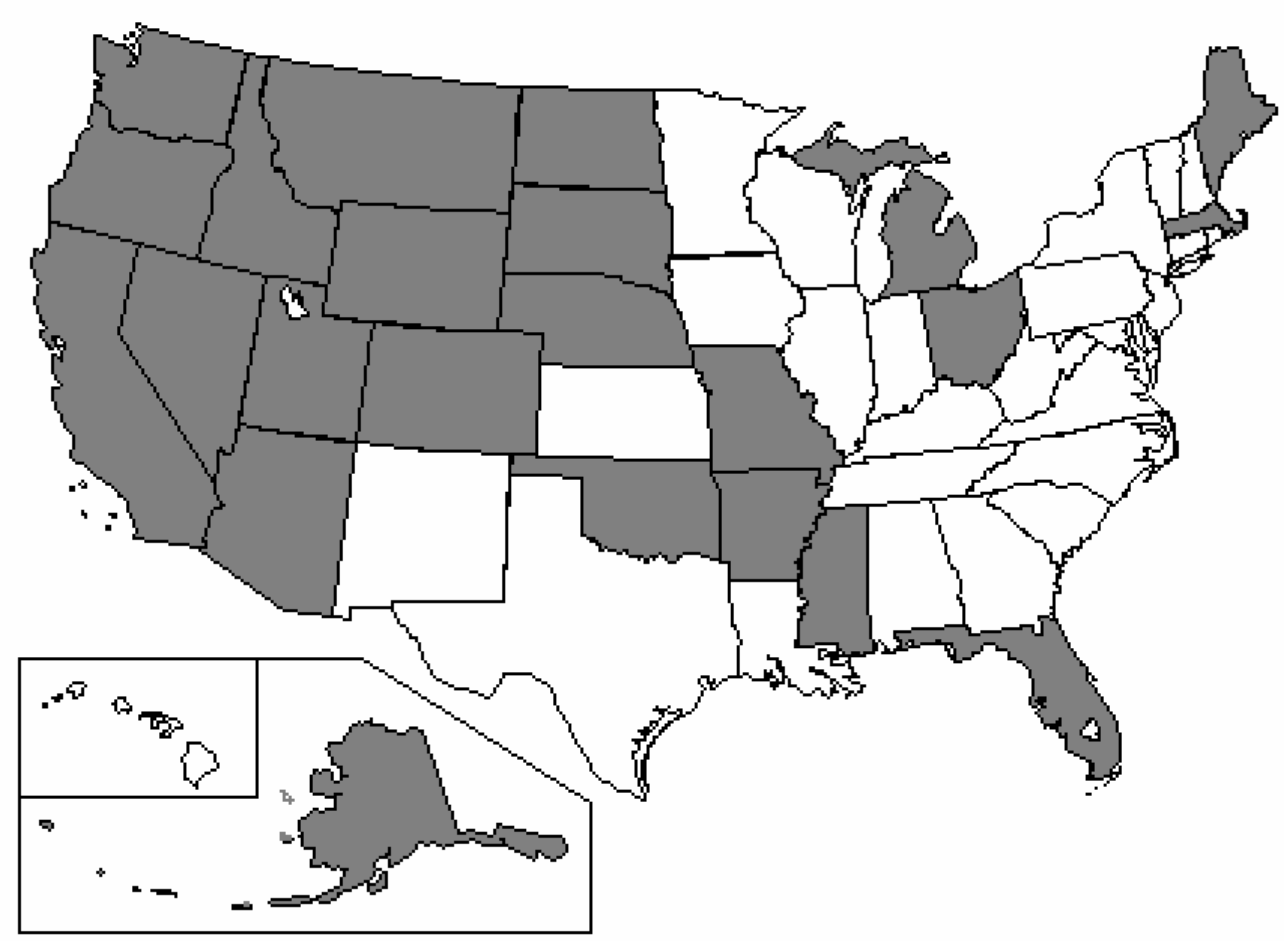

Note: The states in which the voter initiative process is available are shaded. All information for the map is from the Initiative and Referendum Institute. The map is from State Outline Maps.

As mentioned previously, almost half of the U.S. states have some form of the voter initiative. However, there are several important differences between voter initiative states that have a significant impact on the usage of the voter initiative. The most important difference between states involves the signature requirement. This determines the number of signatures that must be collected in order to successfully place a voter initiative on the ballot. The signature requirements range from $3 \%$ to $15 \%$ across states with the voter initiative process and generally apply to either the votes cast in the previous governor's election or the votes cast in the previous general election. A higher signature requirement tends to make the proposition of a voter 
initiative more difficult. Table 2.1 displays the primary differences among states in which the voter initiative process is available.

There are a few other differences in the voter initiative process between voter initiative states. The constitutional initiative process and the statutory initiative process are the two types of voter initiative processes that are available. Constitutional initiatives allow the voters to propose constitutional amendments and are available in 18 states. Statutory initiatives allow the voters to propose laws or memorials and are available in 21 states. Additionally, the process can be further classified into direct and indirect methods. A direct initiative is placed directly on the ballot where voters directly decide the outcome. An indirect initiative is first submitted to the state legislature. It is then considered by the legislature before it appears on the ballot. States differ in the availability of direct and indirect initiatives as well.

The differences in the voter initiative process among states can have a large effect on the impact of the voter initiative. For example, the signature requirement in Wyoming is $15 \%$ of the votes cast in the previous legislative election. It is difficult to gather such a high number of signatures (especially in a state with low population density) in comparison to a state with a relatively low signature requirement (i.e. California with a 5\% signature requirement). For this

reason, Wyoming is often excluded from the voter initiative states for research purposes. Due to the signature requirement differences and other dissimilarities in the voter initiative process among the U.S. states, the usage and effects of the voter initiative process can vary across states.

\subsection{Usage of the Voter Initiative in U.S. States}

The voter initiative has contributed to important policy changes throughout the history of its availability in U.S. states. The voter initiative has been used to address issues from a wide range 
Table 2.1 - Voter Initiative State Differences

\begin{tabular}{|c|c|c|c|c|c|c|c|c|c|}
\hline \multirow[t]{2}{*}{ State } & \multirow{2}{*}{$\begin{array}{c}\text { Date } \\
\text { Initiative } \\
\text { Adopted } \\
\end{array}$} & \multicolumn{2}{|c|}{$\begin{array}{l}\text { Type of Initiative } \\
\text { Process Available }\end{array}$} & \multicolumn{2}{|c|}{$\begin{array}{l}\text { Type of Initiative to Propose } \\
\text { Constitutional Amendments }\end{array}$} & \multicolumn{2}{|c|}{$\begin{array}{l}\text { Type of Initiative Process } \\
\text { to Propose Statutes }\end{array}$} & \multicolumn{2}{|c|}{$\begin{array}{c}\text { Signature Requirement } \\
\text { (\% Voters) }\end{array}$} \\
\hline & & $\mathrm{CA}$ & Statute & Direct & Indirect & Direct & Indirect & $\mathrm{CA}$ & Statute \\
\hline Alaska & 1959 & $\mathrm{O}$ & $\mathrm{X}$ & $\mathrm{O}$ & $\mathrm{O}$ & $\mathrm{X}$ & $\mathrm{O}$ & $\mathrm{O}$ & 10 \\
\hline Arizona & 1912 & $X$ & $\mathrm{X}$ & $\mathrm{X}$ & $\mathrm{O}$ & $\mathrm{X}$ & $\mathrm{O}$ & 15 & 10 \\
\hline Arkansas & 1909 & $X$ & $\mathrm{X}$ & $\mathrm{X}$ & $\mathrm{O}$ & $\mathrm{X}$ & $\mathrm{O}$ & 10 & 8 \\
\hline California & 1911 & $\mathrm{X}$ & $\mathrm{X}$ & $\mathrm{X}$ & $\mathrm{O}$ & $\mathrm{X}$ & $\mathrm{O}$ & 8 & 5 \\
\hline Colorado & 1912 & $\mathrm{X}$ & $\mathrm{X}$ & $\mathrm{X}$ & $\mathrm{O}$ & $\mathrm{X}$ & $\mathrm{O}$ & 5 & 5 \\
\hline Florida & 1972 & $X$ & $\mathrm{O}$ & $\mathrm{X}$ & $\mathrm{O}$ & $\mathrm{O}$ & $\mathrm{O}$ & 8 & $\mathrm{O}$ \\
\hline Idaho & 1912 & $\mathrm{O}$ & $\mathrm{X}$ & $\mathrm{O}$ & $\mathrm{O}$ & $\mathrm{X}$ & $\mathrm{O}$ & $\mathrm{O}$ & 6 \\
\hline Maine & 1908 & $\mathrm{O}$ & $\mathrm{X}$ & $\mathrm{O}$ & $\mathrm{O}$ & $\mathrm{O}$ & $\mathrm{X}$ & $\mathrm{O}$ & 10 \\
\hline Massachusetts & 1918 & $X$ & $\mathrm{X}$ & $\mathrm{O}$ & $\mathrm{X}$ & $\mathrm{O}$ & $\mathrm{X}$ & 3 & 3.5 \\
\hline Michigan & 1908 & $\mathrm{X}$ & $\mathrm{X}$ & $\mathrm{X}$ & $\mathrm{O}$ & $\mathrm{O}$ & $\mathrm{X}$ & 10 & 8 \\
\hline Mississippi & 1992 & $\mathrm{X}$ & $\mathrm{O}$ & $\mathrm{O}$ & $\mathrm{X}$ & $\mathrm{O}$ & $\mathrm{O}$ & 12 & $\mathrm{O}$ \\
\hline Missouri & 1906 & $\mathrm{X}$ & $\mathrm{X}$ & $\mathrm{X}$ & $\mathrm{O}$ & $\mathrm{X}$ & $\mathrm{O}$ & 8 & 5 \\
\hline Montana & 1904 & $X$ & $\mathrm{X}$ & $\mathrm{X}$ & $\mathrm{O}$ & $\mathrm{X}$ & $\mathrm{O}$ & 10 & 5 \\
\hline Nebraska & 1912 & $X$ & $\mathrm{X}$ & $\mathrm{X}$ & $\mathrm{O}$ & $\mathrm{X}$ & $\mathrm{O}$ & 10 & 7 \\
\hline Nevada & 1904 & $X$ & $\mathrm{X}$ & $\mathrm{X}$ & $\mathrm{O}$ & $\mathrm{O}$ & $\mathrm{X}$ & 10 & 10 \\
\hline North Dakota & 1914 & $\mathrm{X}$ & $\mathrm{X}$ & $\mathrm{X}$ & $\mathrm{O}$ & $\mathrm{X}$ & $\mathrm{O}$ & 4 & 2 \\
\hline Ohio & 1912 & $\mathrm{X}$ & $\mathrm{X}$ & $\mathrm{X}$ & $\mathrm{O}$ & $\mathrm{O}$ & $X$ & 10 & 6 \\
\hline Oklahoma & 1907 & $X$ & $\mathrm{X}$ & $\mathrm{X}$ & $\mathrm{O}$ & $\mathrm{X}$ & $\mathrm{O}$ & 15 & 8 \\
\hline Oregon & 1902 & $X$ & $X$ & $X$ & $\mathrm{O}$ & $\mathrm{X}$ & $\mathrm{O}$ & 8 & 6 \\
\hline South Dakota & 1898 & $\mathrm{X}$ & $\mathrm{X}$ & $\mathrm{X}$ & $\mathrm{O}$ & $\mathrm{X}$ & $\mathrm{O}$ & 10 & 5 \\
\hline Utah & 1900 & $\mathrm{O}$ & $\mathrm{X}$ & $\mathrm{O}$ & $\mathrm{O}$ & $\mathrm{X}$ & $\mathrm{X}$ & $\mathrm{O}$ & 10 \\
\hline Washington & 1912 & $\mathrm{O}$ & $\mathrm{X}$ & $\mathrm{O}$ & $\mathrm{O}$ & $\mathrm{X}$ & $X$ & $\mathrm{O}$ & 8 \\
\hline Wyoming & 1968 & $\mathrm{O}$ & $\mathrm{X}$ & $\mathrm{O}$ & $\mathrm{O}$ & $\mathrm{X}$ & $\mathrm{O}$ & $\mathrm{O}$ & 15 \\
\hline Totals & 24 states & 18 states & 21 states & 16 states & 2 states & 16 states & 7 states & 17 states & 21 states \\
\hline
\end{tabular}

Legend: $\mathrm{X}=$ Process allowed by state constitution $\quad \mathrm{O}=$ Process not allowed by state constitution $\mathrm{CA}=$ Constitutional Amendment

All data is from the Initiative \& Referendum Institute. 
of ideologies as well. The movement started in the late $20^{\text {th }}$ century with populists and progressives as the driving force. Conservatives, liberals, and libertarians have affected policy outcomes through the voter initiative process in the last century (Initiative and Referendum Institute). From 1904 through 2006, 2231 voter initiatives have appeared on state ballots. 887 of the voter initiative proposals were adopted by voters. Approximately $40 \%$ of the voter initiatives that appear on the ballot are approved by the voters. While 24 states currently have the voter initiative process available, over $60 \%$ of the voter initiative activity occurs in six states: Arizona, California, Colorado, North Dakota, Oregon, and Washington (Initiative and Referendum Institute).

The usage of the voter initiative process has fluctuated rather substantially over time. Figure 2.2 shows the usage of the voter initiative by decade in U.S. states. The voter initiative was used substantially from 1910 through 1940. However, usage of the voter initiative decreased steadily in the 1940's and continued to decline until the 1970's. Scholars believe that the decline in the usage of the voter initiative was largely due to the Great Depression and the wars that took place during the time (Initiative and Referendum Institute). The new age of the voter initiative was ushered in with the passage of Proposition 13 in California in 1978. Usage of the voter initiative increased throughout the 1980's and 1990's. While usage has not been as high in the first decade of the $21^{\text {st }}$ century as in the end of the $20^{\text {th }}$ century, the voter initiative has continued to play a large role in shaping policy in U.S. states. 79 voter initiatives appeared on the ballots in 2006. Proposition 187 in California set a spending record with over $\$ 150$ million spent by competing interest groups.

\subsection{Important Issues in the Voter Initiative Literature}


Figure 2.2: Number of Voter Initiatives Proposed and Passed by Decade

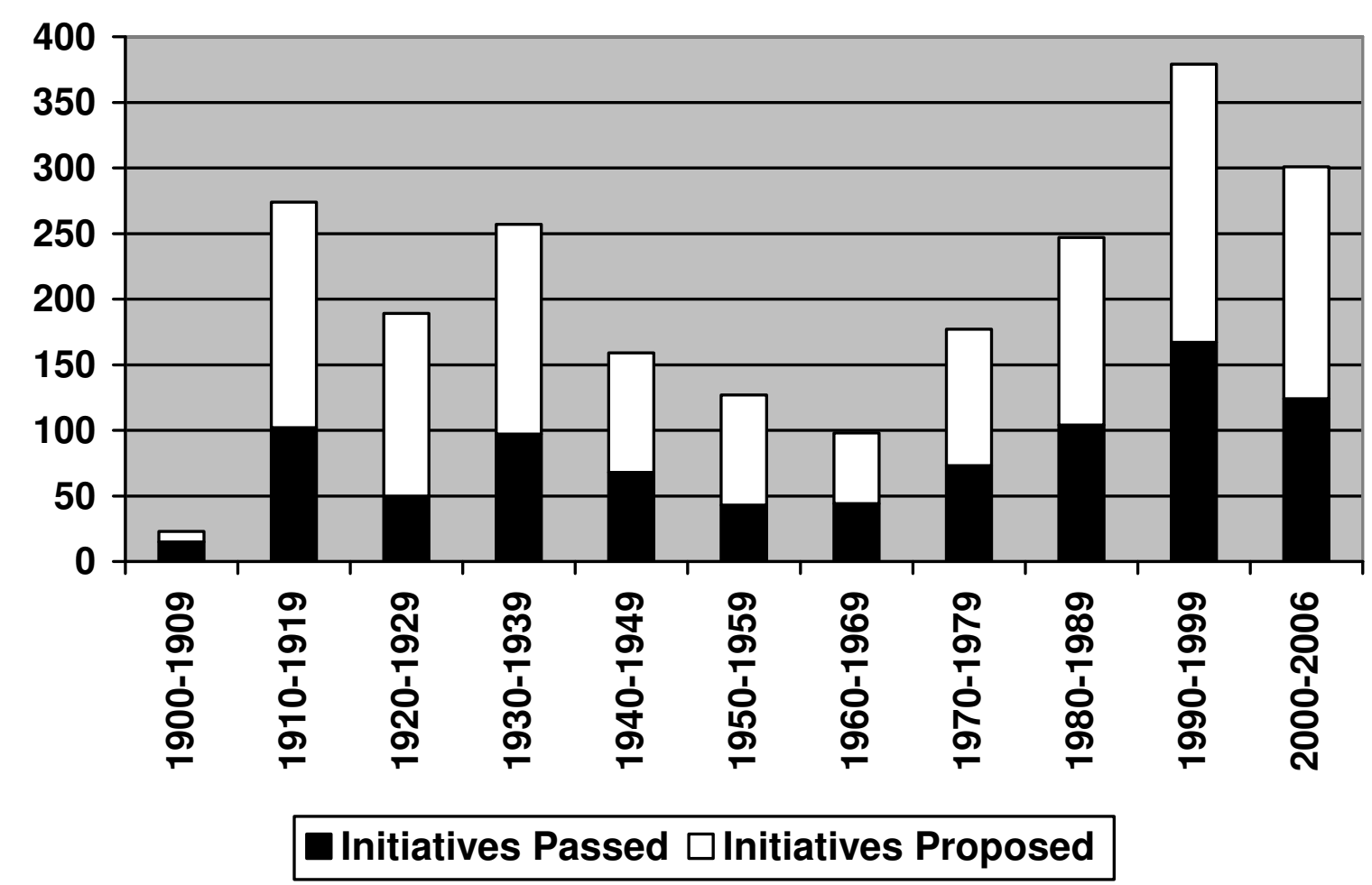

Note: All data is from the Initiative and Referendum Institute.

While it is complicated to objectively assess whether the voter initiative improves the performance of the government, the recent literature has addressed several issues in order to evaluate the voter initiative process. Matsusaka (2004, 2005a) provides an extensive assessment of the subject by examining the theory behind the voter initiative and the crucial components of the argument. The role of money in the voter initiative process, voter competence, and the key issue of whether the voter initiative leads to policies that favor the views of the median voter must be addressed in the evaluation of the voter initiative process.

In order to evaluate the voter initiative process, it is quite useful to outline several issues that are closely related to the voter initiative process. This involves examining agency problems, 
logrolling and candidate positions, and information quality in order to understand how the voter initiative operates under different circumstances (Matsusaka 2005a). Agency problems can exist among legislators because constituents may not be able to effectively supervise and control the behavior of elected officials (Kau \& Rubin 1979, Kalt \& Zupan 1984, Peltzman 1984). If legislators are pursuing activities contrary to the views of the median voter, then the voter initiative can offer a method by which the general public can directly alter the policy set by legislators. The availability of the voter initiative process can also have an indirect effect on the decisions of legislators. Legislators may consider the possibility that constituents can propose a voter initiative when making decisions, which could alter the final decision of the elected officials (Matsusaka 2005a). Both of these effects should tend to benefit the median voter. In order for a voter initiative to pass and directly affect policy, a majority of voters must agree with the voter initiative. In order for the legislators to alter a decision due to the possibility of a voter initiative, the legislators must perceive the voter initiative as an imminent credible threat. This can only happen when the legislators believe that a majority of voters will support a voter initiative. The result will tend to be a policy that is more aligned with the views of the median voter. However, the voter initiative process does not guarantee that policies will be precisely aligned with the views of the median voter. Voters are only afforded the options of the policy that is supported by the legislators and the policy that is offered by an interest group as a voter initiative (Romer \& Rosenthal 1979). Additionally, it is possible that the availability of the voter initiative could cause the legislators to enact policies that actually harm the median voter if asymmetric information is present (Matsusaka 2005a). If legislators mistakenly perceive that the threat of a voter initiative from a narrow economic interest group or extreme interest group as the 
beliefs of the median voter, the legislators may enact a policy contrary to the views of the median voter (Gerber and Lupia 1995, Matsusaka and McCarty 2001).

The voter initiative is also able to give individuals an opportunity to combat logrolling, the process of vote trading among legislators in which a number of issues are bundled into one bill and voted on as a whole. Citizens have the opportunity to challenge individual issues through the voter initiative process (Matsusaka 2005a). If logrolling is a process that results in inefficient spending on pork barrel politics (Buchanan \& Tullock 1962), then the voter initiative may help lead to a reduction in inefficient spending. However, if the process of logrolling results in efficient outcomes due to legislators trading for the policies that they prefer the strongest (Buchanan \& Tullock 1962), then it is possible that the voter initiative could result in a decrease in efficiency (Matsusaka 1995). The voter initiative also allows individuals to separate candidates from certain issues. If citizens are able to challenge policies with the voter initiative, then candidates will have fewer issues on which to take positions when running for election. Besley and Coate (2003) and Matsusaka (2005a) find that voters can better identify and elect candidates that support the most important issues in the voter's minds when the candidates support fewer issues in general.

The issue of information quality must also be considered in the voter initiative process. The main point of contention rests in the question of whether individuals have the necessary information to make appropriate decisions. Following the logic of Hayek (1945), information that is dispersed in the minds of the people cannot be completely known by any number of politicians. According to this reasoning, the voter initiative may allow for better decisions as individuals are given an avenue to express their true desires. However, opponents of the voter initiative argue that the voters do not possess the proper information to make decisions. Maskin 
and Tirole (2004) propose that legislators possess information that voters do not, which suggests that the voter initiative process could lead to harmful decisions. Additionally, Kessler (2005) finds that use of the voter initiative may cause legislators to invest less time attempting to collect and gauge information from the voters. However, the process of voting results in the compilation of the information that is in the minds of millions of voters. According to the law of large numbers, it is possible that this combination can help overcome information problems even if any individual voter has a small probability of possessing accurate information (McLennan 1998, Lupia 2001).

While the issue of informational quality continues to be debated, Matsusaka (1992) suggests that the effectiveness of the voter initiative may depend on the nature of the issue. He reasons that issues that involve value based judgments may be best decided by the voters because the necessary information for these decisions rests in the mind of the voters. Technical issues that involve the knowledge of specific details may be best decided by experts. He finds some evidence that issues are decided in this manner.

The examination of the situations in which the voter initiative may be beneficial or harmful is useful to help evaluate the debated issues surrounding the voter initiative process. The first point of contention involves the issue of money. Huge sums of money are involved in the voter initiative process. For example, the cost of gathering the required signatures to simply place a voter initiative on the ballot in California exceeds $\$ 1$ million dollars. This fails to include any costs of supporting or campaigning against the voter initiative (Matsusaka 2005a). For example, California's Proposition 187 involved over $\$ 150$ million in spending. Opponents of the voter initiative process view the large amounts of money involved in the process as beneficial to narrow special interest groups. The basic idea is that these groups can spend large sums of 
money to get voter initiatives on the ballot and then convince voters to support the voter initiatives. However, reasoning seems to suggest that the voter initiative poses less of a threat of subversion to special interest groups than elected legislators. Once legislators are elected, they are able to direct resources to campaign contributors without the consent of the voters. The voter initiative at least allows the possibility for the voters to reject a policy that does not have the support of the majority (Matsusaka 2004).

Furthermore, recent studies suggest that while money does play an important role in the voter initiative process, large money expenditures does not necessarily lead to the passage of voter initiatives $^{3}$. Gerber (1999) finds that spending generally has small and insignificant effects on the probability of succeeding with a voter initiative. This finding appears to be the result of the resources available to narrow special interest groups. The special interest groups generally have large amounts of money, but often lack the support of the voters. It is unlikely that spending money will be able to change the minds of the voters, especially if the voter initiative appears to directly benefit narrow interest groups. On the other hand, broad based citizen groups may be better at successfully passing voter initiatives due to a larger support base. These groups have larger membership bases and often sponsor issues that are supported by larger proportions of the population. Lupia (1994) and Lupia and Johnston (2001) also find that spending large sums of money generally does not assist in the passage of initiatives that are supported by narrow interest groups. Broad based support is necessary for the passage of a voter initiative.

Despite the fact that special interest groups may not be able to successfully enact policy changes directly through the voter initiative process, they may be able to garner enough interest

\footnotetext{
${ }^{3}$ Lowenstein (1982) and Magleby (1984) initially examined this issue with basic comparisons. The rates of passage for voter initiatives in which opposing sides spent equivalent amounts of money were compared to the rates of passage for voter initiatives where one side largely outspent the other. Both studies found large spending differences to have a very small effect on the rate of passage of voter initiatives. However, they also found that large spending often can help defeat voter initiatives.
} 
in the topic for the legislators to enact policies that are better aligned with the interest group's preferences. If the interest group can signal to the legislators that some proposed policy measure is supported by a decent share of the voters, the legislators may perceive the proposed voter initiative as a threat. Rather than risk the possibility of the passage of a voter initiative that could result in an unfavorable outcome in views of the legislators, the legislators may enact a policy that benefits the special interest group (Matsusaka 2004). Gerber (1999) finds that businesses often propose and support voter initiatives primarily to influence the actions of legislators. The findings were obtained through the use of surveys of business groups.

While money may not improve the success rate of voter initiatives, it does seem to play a large role in the defeat of voter initiatives. Bowler and Donovan (1998) find that voters generally refute voter initiatives when the outcomes of the initiative appear unclear. Voters seem to choose to remain with the current policy when this situation arises due to the fear that a new policy may result in harmful consequences. Matsusaka (2004) suggests that interest groups that spend money to defeat a voter initiative may be successful if the campaign generates uncertainty among voters. Gerber (1999) finds that spending tends to have large and significant effects on the probability of defeating a voter initiative.

A second issue of discord among the proponents and opponents of the voter initiative involves voter competence. The American voters are often perceived to be incompetent when it comes to knowledge of basic politics and issues involving the government ${ }^{4}$. Delli Carpini and Ketter (1996) display that voters incorrectly answer questions involving politics and government on a regular basis. However, Matsusaka $(2004,2005 a)$ suggests that voters do not necessarily need to possess all of the information pertaining to an issue in order to correctly take a position

\footnotetext{
${ }^{4}$ Magleby (1984) and Broder (2001) suggest that voters are persuaded by expensive advertising and are incapable of making complex voting decisions due to a lack of proper knowledge.
} 
according to their preferences. He notes that individuals routinely make decisions based on very limited amounts of information. Voters can use information from various sources, including friends, news, and interest groups, in order to choose the correct stance on an issue.

Several studies support the concept that voters can project their true preferences through voting on voter initiatives despite a lack of knowledge surrounding the specific details of the issue. Lupia (1994) used exit poll surveys involving five California voter initiatives in 1988 to examine the impact of information on voting. While the five voter initiatives involved rather complex details about insurance issues, Lupia found that voters who knew little about the specific details of the voter initiatives could reproduce the voting preferences of informed voters if they knew the position of the insurance group supporting the voter initiative. While the uninformed voters could not answer questions relating to the specific details of the propositions, they were able to correctly vote according to their preferences due to the information signals from the supporting interest groups. Uninformed voters that could not identify the positions of interest groups were unable to display their true preferences and voted quite differently than the other two groups. Bowler and Donovan (1998) find that voters are generally able to reveal their true preferences and values through the voter initiative process. Additionally, they find that voters tend to simply vote against issues that they lack the necessary information in which to make a decision that reflects their true preferences. ${ }^{5}$

Although evidence seems to suggest that a lack of voter competence does not pose a serious problem to the voter initiative, Matsusaka (2005a) argues that the overall effectiveness of

\footnotetext{
${ }^{5}$ Additional studies conclude that individuals are competent to make decisions involving the voter initiative. According to Lupia and Johnston (2001), allowing voters to decide on policy issues using the voter initiative does not harm outcomes in societies with open channels of communication. Kahn and Matsusaka (1997) and Kahn (2002) find that individuals vote in favor of voter initiatives that result in economic benefits for the individual while voters will vote against legislation that harms their economic interests.
} 
democracy in general would be the primary concern if voters lacked the knowledge to correctly convey their preferences. When selecting a candidate for office, voters must choose among candidates supporting a bundle of issues. Voters often are not familiar with all of the specific positions that a candidate holds. In the case of the voter initiative, the voter is only deciding on one issue. If concerns over the competence of voters are a serious issue, the entire democratic process would be affected.

While the role of money in the voter initiative process and the issue of voter competence are important parts of the debate surrounding the voter initiative, the policies that are the result of the voter initiative process are the most important measure of the value of the voter initiative process. Recent investigations have empirically analyzed the impact of the voter initiative on policy outcomes rather than relying on the relatively subjective analysis that was typical of the studies of the past. Matsusaka (2004) examined spending and taxation in U.S. states in order to evaluate the impact of the voter initiative. He finds that states in which the voter initiative process is available tend to have lower levels of state spending and lower taxes, employ more user fees, and spend more at the local government level than states in which the voter initiative process is unavailable. He then examines opinion surveys from U.S. states and finds that the vast majority of individuals support the policies that are found in states in which the voter initiative is available. This seems to suggest that the median voter benefits from the availability of the voter initiative process.

Additional research also seems to suggest that the voter initiative helps to move policy toward the preferences of the median voter. Gerber $(1996,1999)$ finds that the death penalty and parental notification of abortions for minors are more prevalent in states in which the voter initiative process is available. She then uses opinion survey data to estimate the preferences of 
the median voter. The findings reveal that the median voter prefers the policies in that are found in voter initiative states. Matsusaka (2004) finds that states in which the voter initiative is available are more likely to have legislative term limits than states that lack the voter initiative process. $^{6}$ Once again, surveys suggest that voter strongly favor term limits for elected officials. This section highlights some of the most notable contributions to the voter initiative literature in recent years. While the recent surge in the usage of the voter initiative has resulted in an increase in research in the area, the voter initiative process continues to receive far less attention than the democratic voting process in general. The remainder of this dissertation contributes to the existing literature by examining the effects of the voter initiative on government spending, the power of the legislative and executive branches, and the production of legislation in U.S. states.

\footnotetext{
${ }^{6}$ Only 2 out of 26 states without the voter initiative process have some type of legislative term limits while 22 out of 24 voter initiative states have some form of term limit.
} 


\section{Chapter 3}

\section{Do Voter Initiatives Affect the Interest Group Orientation of Government Spending?}

\subsection{Introduction}

The recently renewed interest in voter initiatives has rekindled a debate surrounding the primary beneficiaries of the voter initiative process. Matsusaka (2005a) outlines the primary arguments on both sides of the debate. Proponents of the voter initiative argue that the voter initiative generally shifts political power away from interest groups and toward the median voter. According to this theory, the voter initiative gives the public a method to check the activities of legislatures that would otherwise tend to cater to narrow special interest groups. The voter initiative also provides an indirect threat to any decisions made by the legislature. The legislators may make decisions that are more aligned with the views of the median voter in order to avoid a possible future voter initiative that might be less favorable to the legislature.

Opponents of the voter initiative, however, believe that well-organized and well-funded special interest groups may actually benefit from the voter initiative at the expense of the median voter. Supporters of this view often point to the massive amounts of money involved in the few voter initiatives that actually appear on the ballot each year. Over $\$ 400$ million was spent on voter initiatives throughout the states in 1998 alone in comparison to \$326 million that was spent by all parties in the 2000 presidential campaign, for example (Matsusaka 2005a). In 2006, spending on California's Proposition 187 eclipsed $\$ 150$ million. This hypothesis is based on several possible lines of reasoning. Special interest groups may be able to motivate their supporters to vote while much of the general population does not vote. Individuals that do vote may lack the knowledge and information to vote in their own best interest, and instead vote in 
favor of a narrow special interest group due to misleading information. Finally, the behavior of legislators may be distorted by the threat of the voter initiative, leading to the passage of laws that harm the general public.

Another important contribution to the voter initiative literature involves the behavior of interest groups when the voter initiative process is available. The voter initiative affords another method by which interest groups can influence policy outcomes. In addition to targeting the votes of the legislature, interest groups may now also covet the direct support of voters. Interest group mobilization tends to increase when the voter initiative process is available as the increase in the expected benefits of mobilization outweighs the expected costs of mobilization (Boehmke 2002, 2005). Additionally, due to the nature of the voter initiative process, broad based citizen groups seem to benefit to a greater extent than narrow economic special interest groups. This results in an increase of broad based citizen group representation relative to other economic special interest groups (Boehmke 2002, 2005).

An interesting related issue is whether the voter initiative is able to change the composition of government spending. Total state government spending should be a quasi-public good because government spending is used for both public and private goods. It would be informative to see if the voter initiative can affect the degree to which government spending is public. A greater level of private spending would suggest that the spending was furthering the welfare of special interest groups. If less private spending were to be found in voter initiative states accounting for other variables, then the evidence would suggest that the voter initiative helps to restrict the influence of special interest groups. This paper examines this issue using a median voter model to estimate the publicness of total state government spending. Section II discusses the effect of the voter initiative on policy outcomes and interest group behavior. 
Section III describes the model. Section IV presents and discusses the empirical results. Section V concludes.

\subsection{Does the Voter Initiative Favor the Median Voter?}

It is difficult to simply judge whether the voter initiative enhances the performance of government due to the subjective nature of the question. However, the general argument concerning the primary beneficiaries of the voter initiative has not changed since Nebraska became the first U.S. state to adopt the voter initiative process over a century ago. Does the voter initiative shift power into the hands of the voters or does it simply provide narrow special interest groups with more power to enact programs in their interests? Although well-organized and well-funded special interest groups probably exert more influence than voters on both the legislature and the voter initiative process (Lupia and Matsusaka 2004), the true question involves the relative shift of power provided by the voter initiative process.

When solely examining the theory behind the voter initiative, the effect of the voter initiative on policy outcomes is ambiguous. ${ }^{1}$ The voter initiative can help overcome agency problems between legislators and constituents, logrolling, and issues involving information quality in some cases. However, the voter initiative can lead to outcomes that are unfavorable to the median voter under other conditions. Additionally, the issues of voter competence and the role of money in the voter initiative process have long been a point of discord between supporters and opponents of the voter initiative (Matsusaka 2004, 2005a, 2005b).

In order to evaluate the results of the voter initiative, it is important to note that the incentive structure for interest groups is altered when the voter initiative is available. Interest

\footnotetext{
${ }^{1}$ See Matsusaka (2004, 2005a, 2005b) for a complete discussion of voter initiative theory.
} 
groups gain the advantage of the ability to directly propose a change in policy with the voter initiative, breaking the monopoly of the legislature. Additionally, the voter initiative can indirectly affect the decisions of legislators as they must consider the threat of a voter initiative when making policy decisions. Due to the possible increase in benefits to interest groups, the voter initiative tends to lead to an increase in the mobilization of interest groups in states that have the voter initiative process (Boehmke 2002, 2005). Boehmke $(2002,2005)$ compares the number of interest groups in voter initiative states to non-initiative states. After controlling for other variables, he finds that the availability of the voter initiative tends to increase the quantity of interest groups. $^{2}$

A key related issue involves the type of interest groups that receive the most benefit from the voter initiative process. Due to the nature of the voter initiative process, it seems reasonable that broad-based citizen groups would have an advantage over narrow economic special interest groups. For example, environmental activists may gain power relative to a concentrated manufacturing industry interest group. In order to successfully propose and possibly pass a voter initiative (or to achieve a policy change indirectly through the threat of a voter initiative), an interest group must be able to generate the support of the majority of the voters. This should be more feasible for citizen groups because they generally encompass a larger share of public support (Boehmke 2005). This becomes especially important if the economic groups are more successful at achieving policy outcomes in the absence of the voter initiative process. ${ }^{3}$ Boehmke (2002, 2005) finds that voter initiative states have a greater relative increase in citizen groups than economic groups. Furthermore, Gerber (1999) finds that citizen groups are more successful

\footnotetext{
${ }^{2}$ Boehmke (2005) finds that states with the voter initiative tend to have about 28 percent more interest groups than non-initiative states.

${ }^{3}$ Many papers have noted the possible influence of special interest groups on the legislature, including Weingast, Shepsle, and Johnsen (1982), McCormick and Tollison (1981), and Holcombe (1985).
} 
at achieving policy changes through the voter initiative process in comparison to narrow special interest groups. ${ }^{4}$

However the crucial determinant of the primary beneficiaries of the voter initiative rests in the policies that are the result of the voter initiative. Until recently, the policy outcomes of the voter initiative process were evaluated on a relatively subjective basis through observations. Matsusaka (2004) provides a compelling empirical assessment of the voter initiative by examining state and local spending and taxation throughout the previous century. His study finds important differences between voter initiative states and non-initiative states. His primary result is that voter initiative states tend to have lower levels of spending and lower taxes. Furthermore, he finds that voter initiative states tend to rely more heavily on user fees as opposed to general taxes. Voter initiative states also tend to spend more at the local level and less at the state level. In order to evaluate the support for these differences in policies, Matsusaka examines results from opinion surveys. He finds that a large majority of the population favors all of these policy differences that can be found in voter initiative states. His study suggests that the voter initiative process does, in fact, benefit the median voter relative to interest groups.

Opinion surveys regarding term limits and social issues seem to further suggest that policies enacted in voter initiative states are favored by the median voter. A vast majority of voter initiative states have a type of legislative term limit while most states that lack the voter initiative process do not. ${ }^{5}$ Surveys suggest that voters strongly support the concept of term limits. This issue is especially important considering that term limits are one issue where

\footnotetext{
${ }^{4}$ Additionally, Bowler, McCuan, and Fernandez (1998) find that a large majority of the voter initiatives proposed in California from 1986 to 1996 were supported by broad based groups. Ernst (2001) found similar results on all state ballots from 1898 to 1995.

${ }^{5}$ Only 2 out of states in which the voter initiative process in unavailable have some type of legislative term limits while 22 out of 24 voter initiative states have some form of term limit.
} 
legislators are placed directly at odds with the voters (Matsusaka 2004). Gerber (1999) finds that voter initiative states are more likely to approve the death penalty and parental notification for abortions. Once again, opinion surveys suggest that these policies are preferred by the majority.

The initial empirical evaluations of the voter initiative imply that the voter initiative leads to the adoption of policies that are supported by the median voter. However critics remain skeptical and view the voter initiative simply as a method by which special interest groups can further their welfare at the expense of the median voter. In fact, Boehmke $(2002,2005)$ finds that a larger number of interest groups exist in states in which the voter initiative process is available. The question clearly merits further investigation as the debate over the primary beneficiary of the voter initiative continues.

\subsection{The Model}

This paper uses an empirical median voter model to estimate the degree of publicness of total state government spending. ${ }^{6}$ Turnbull and Mitias (1995) provide justification for the use of this empirical median voter model. The model has been used to examine the demand for public goods and services by Borcherding and Deacon (1972) and Bergstrom and Goodman (1973). Deno and Mehay (1987) examine two different government forms and the related levels of expenditure with the model. A publicness measure of legislative activities is tested by Holcombe and Sobel (1995). Additional examples include Langbein's (2004) estimation of the publicness in public school music using the median voter model and King's (2006) examination of the spillover effects of public education. A higher degree of private spending suggests that interest groups exert a larger impact on spending. Special interest legislation is a private good as the

\footnotetext{
${ }^{6}$ Bowen (1943) originally constructed the model. Downs (1957) and Black (1958) further contributed to the theory behind the model.
} 
benefits accrue to specific members of the population. The voter initiative would restrain the influence of interest groups if less private spending were to be found in states in which the voter initiative process is available.

When considering a pure public good, the optimal amount of the good provided in a state should not change when an additional individual relocates into the state. This is due to the fact that pure public goods are joint-in consumption. An extra individual can share in the amount of the pure public good that is already provided in the state. For example, no further highway spending would be required for an additional individual to use an uncongested rural highway. On the other hand, the amount of spending for a pure private good will increase as additional individuals relocate to a state. Spending on a state farm subsidy program, for example, would expand if an additional farmer moved into the state. These goods are consumed by an individual and are not joint-in-consumption. When examining total state spending, it seems reasonable that a percentage of the spending will be private while the rest will be public. The publicness estimate will measure the percentage of government spending that is public.

The estimation of publicness explains the summation of individual demand curves in the market for total government spending. Pure private goods are rival-in-consumption and a horizontal summation of individual demand curves must be used in order to arrive at the social benefit curve. Total benefit is simply limited to the benefit that accrues to the individual consumer. Pure public goods are joint-in-consumption and the corresponding individual demand curves are added vertically. Society shares the benefits provided by these goods. The degree to which the individual demand curves are added vertically or horizontally to create the social benefit curve is estimated by the publicness measure (King 2006). A good with a greater degree of publicness would result in a larger angle with a more vertical summation of individual 
demand curves. A smaller angle would suggest a more horizontal summation of individual demand curves due to a good that is private to a larger degree. This relationship is displayed in Figure 3.1.

Assuming that total state government expenditure is determined in a political framework and voters have demands for the output generated by the expenditures, the median voter model can be used to estimate the demand for government provided goods. ${ }^{7}$ Voters will base their decision for the amount of desired government provided goods on the comparison of the marginal benefits of government provided goods with their marginal tax prices. The median voter will be decisive in the determination of the amount of government provided goods. The utility function of the median voter is as follows

$$
U_{i}=U_{i}\left(X_{i}, s_{i}\right)
$$

where $s_{i}$ is the amount of government provided goods consumed by the median voter and $X_{i}$ is the total amount of other goods consumed. The amount of government provided goods consumed by the median voter $\left(s_{i}\right)$ is related to the total amount of government provided goods $(S)$ through the function

$$
s_{i}=N^{-\gamma} S
$$

in which $\mathrm{N}$ represents the total state population.

A value of $\gamma=0$ would imply that government provided goods are pure public goods, while a value of $\gamma=1$ would imply that government provided goods are purely private. When $\gamma=0, s_{i}=S$ and each individual consumes the total amount of the good available. When

\footnotetext{
${ }^{7}$ Inman (1978) and Holcombe (1980) provide empirical evidence suggesting that the median voter is decisive in majority rules politics.
} 


\section{Figure 3.1: Publicness Measure}

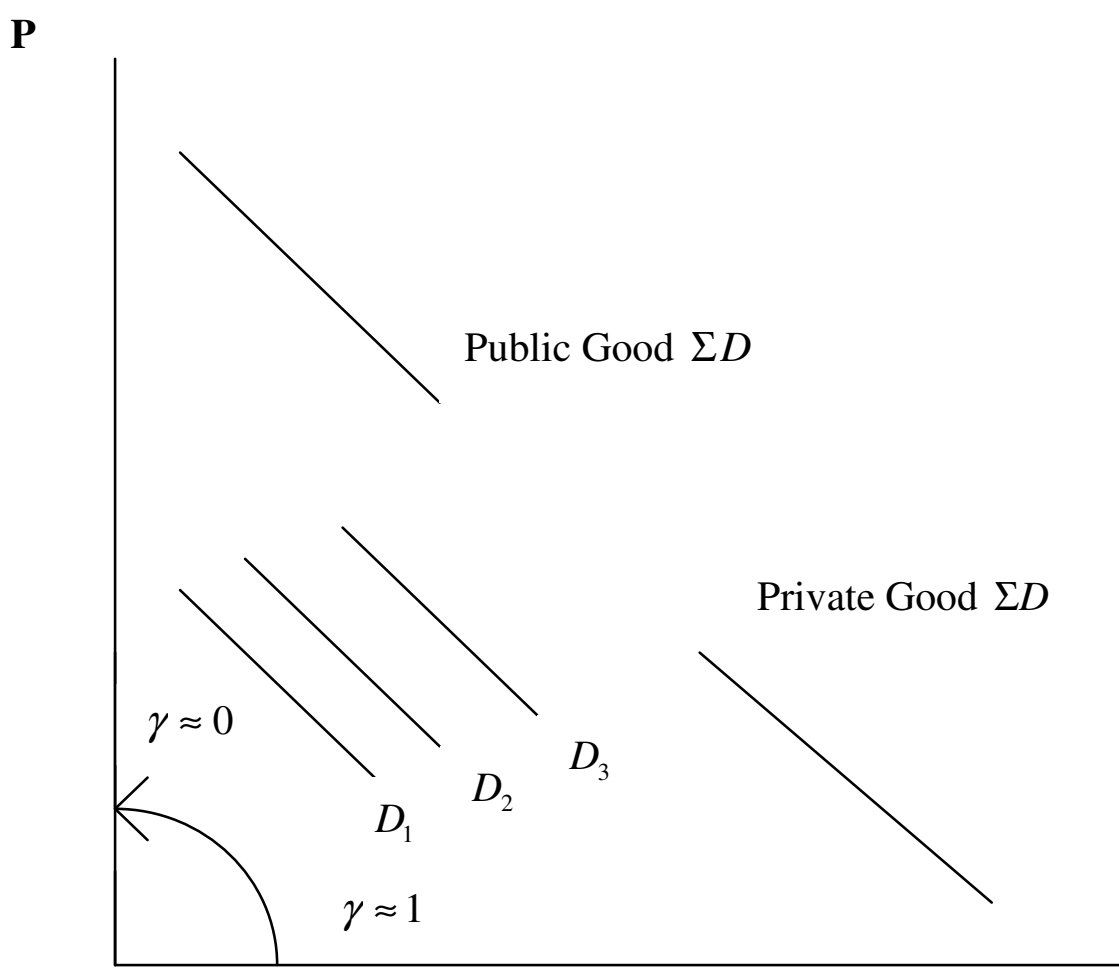

Q

Individual demand curves are represented by $D_{1}, D_{2}$, and $D_{3} . \gamma$ is reflected in the angle that is the result of either a horizontal or vertical summation of the individual demands for a good. A measure of $\gamma$ equal to zero implies a public good with a vertical demand summation. A measure of $\gamma$ equal to one implies a private good with a horizontal demand summation. A value of $\gamma$ between zero and one is the result of a quasi-public good.

$\gamma=1, s_{i}=S / N$ and each individual consumes an equal fraction of the good available. A quasipublic good would be the result of any value of $\gamma$ between 0 and 1. A relatively more public good would be accompanied by a value of $\gamma$ closer to zero.

In order to reveal the median voter's demand function for government provided goods, (1) is maximized subject to the budget constraint 


$$
Y_{i}=P_{x} X_{i}+T_{i} P_{S} S
$$

where $Y_{i}$ is the median voter's disposable income, $P_{X}$ is the price of other goods $X, T_{i}$ is the tax share of the median voter, and $P_{S}$ is the price per unit of government provided goods.

The budget constraint can be rewritten after substituting from equation (2) as

$$
Y_{i}=P_{X} X_{i}+T_{i} P_{S} s_{i} N^{\gamma}
$$

which generates the demand equation through optimization

$$
s_{i}=s_{i}\left(P_{X}, T_{i}, P_{S}, N, T_{i}\right)
$$

Following the previous literature, I assume that $P_{X}$ and $P_{S}$ are the same across states for empirical purposes. Including a vector $A$ to represent differences in preferences across states and using a constant elasticity demand function, the following is obtained

$$
s_{i}=A\left(T_{i} N^{\gamma}\right)^{\alpha} Y_{i}^{\lambda}
$$

Substituting $s_{i}$ from (2) into (6) represents the total demand for $S$ as follows

$$
S=A T_{i}^{\alpha} N^{\gamma(1+\alpha)} Y_{i}^{\lambda}
$$

or alternatively

$$
S=A T_{i}^{\alpha} N^{\delta} Y_{i}^{\lambda}
$$

where $\delta=\gamma(1+\alpha)$. The demand equation for the median voter in log form is

$$
\ln S=\ln A+\alpha \ln T_{i}+\delta \ln N+\lambda \ln Y_{i}
$$

The median voter's disposable income $Y_{i}$ is calculated as 


$$
Y_{i}=Y_{i}^{*}+T_{i} G-F
$$

where $Y_{i}^{*}$ is gross state median income, $G$ is the amount of federal grants to the median voter's state, ${ }^{8}$ and $F$ is the federal tax liability of the median voter. ${ }^{9} T_{i} G$ is used to represent the share of federal grants that accrue to the median voter. This requires the assumption that the voter's tax share is equivalent to the voter's share in the benefit of federal grants. ${ }^{10} T_{i}$ is calculated by taking the effective average tax rate on sales and income taxes ${ }^{11}$ and multiplying by the median income in order to obtain the median state sales and income tax liability, and then dividing the value by total state general sales and income tax revenue. ${ }^{12}$

Due to differences in voter preferences across states, other variables are included from parameter $A$ in (9) to give us the following empirical specification

$$
\begin{aligned}
& \ln S=\beta_{1}+\beta_{2} \ln T_{i}+\beta_{3} \ln N+\beta_{4} \ln Y_{i}+\beta_{5} \ln D E N \\
& \quad+\beta_{6} \ln A G E+\beta_{7} \ln N W+\beta_{8} \ln L O C A L+\beta_{9} C P O P+\varepsilon
\end{aligned}
$$

where $D E N$ is state population density, $A G E$ is median state age, $N W$ is the state percentage of non-white population, LOCAL is the state number of county and municipal governments per square mile, $C P O P$ is the state growth rate of population, and $\varepsilon$ is the error term. ${ }^{13}$

\footnotetext{
${ }^{8}$ Borcherding and Deacon (1972) justify the inclusion of federal government grants in the calculation of state disposable income for voters.

${ }^{9}$ Federal tax liability was calculated by finding the relevant federal income tax for state median income. Inman (1978) provides evidence that median voter data is appropriate for voting models.

${ }^{10}$ Gramlich (1968) and Wilde (1968) indicate that federal grants are in theory a good substitute for state revenues.

${ }^{11}$ The effective average tax rate on sales and income tax was taken directly from Feenberg and Rosen (1985) for 1980. The 1990 and 2000 effective tax rates are borrowed from the National Center for Higher Education Management Systems.

${ }^{12}$ The examples of papers employing the median voter model previously mentioned use this method to calculate disposable income.

${ }^{13}$ Wyoming is excluded as a voter initiative state due to its extremely large signature requirement (15 percent). Illinois is excluded because it is the only state that limits usage of the voter initiative to changes in the organization
} 
In order to estimate the difference in the measure of publicness between voter initiative states and states in which the voter initiative process is unavailable, interaction terms are included to capture the marginal effect of the tax share and population variables in voter initiative states. Including $I$ as a dummy variable for voter initiative states, the following empirical specification is obtained

$$
\begin{aligned}
\ln S= & \beta_{1}+\beta_{2} \ln T_{i}+I^{*} \beta_{3} \ln T_{i}+\beta_{4} \ln N+I^{*} \beta_{5} \ln N+\beta_{6} \ln Y_{i}+\beta_{7} \ln D E N \\
& +\beta_{8} \ln A G E+\beta_{9} \ln N W+\beta_{10} \ln L O C A L+\beta_{11} C P O P+\varepsilon
\end{aligned}
$$

The measure of publicness is calculated as

$$
\gamma=\delta /(1+\alpha)
$$

The resulting value determines the percentage of private spending. ${ }^{14}$ The measure of the publicness of government spending in non-initiative states $\left(\gamma_{N}\right)$ is calculated from (12) as:

$$
\gamma_{N}=\left(\beta_{4}\right) /\left(1+\beta_{2}\right)
$$

where $\beta_{2}$ is the estimated elasticity of state government expenditure with respect to population and $\beta_{4}$ is the estimated elasticity of state government expenditure with respect to tax share. The measure of the publicness of government spending in voter initiative states $\left(\gamma_{I}\right)$ is calculated from (12) as:

of the state's legislature. This follows the work of Matsusaka (2004). Including Wyoming or Illinois does not significantly alter the results.

${ }^{14}$ As mentioned earlier, because they are joint-in-consumption, government spending on public goods will not directly change when population increases. Spending on private goods, however, will increase. However, one factor that complicates this distinction is that even with a pure public good, when another person shares in the consumption of the public good, it also results in a reduction in the tax share per person. Thus, for a pure public good, this increase in population would result in a reduction in the cost per person (the tax share) as individuals relocate to the state other things constant. As this price falls, the quantity demanded of government provided goods will increase. Therefore, the optimal amount of total government spending will increase as individuals relocate to a state regardless of the relationship between total state spending and population. This is why the publicness parameter is a nonlinear combination of both the population and tax share elasticities. 


$$
\gamma_{I}=\left(\beta_{4}+\beta_{5}\right) /\left(1+\beta_{2}+\beta_{3}\right)
$$

$\beta_{3}$ and $\beta_{5}$ add the marginal effect of the voter initiative to the elasticity of state government expenditure with respect to population and tax share, respectively. The calculated statistics $\gamma_{N}$ and $\gamma_{I}$ can be interpreted as the degree to which total state government spending is a private good. A value of 1 would suggest that total state spending is entirely private while a value of 0 would suggest it to be purely public.

\subsection{Empirical Results}

The empirical specification (12) was estimated using state government expenditure data. The data sources are listed in the appendix. The first estimation was performed using cross section data only for 1980. The second estimation uses pooled cross section data from both 1990 and 2000. These were estimated separately due to differences in the available measure of the effective average tax rate on sales and income for the different years. ${ }^{15}$ A third estimation is performed using pooled cross section data for the combination of all three years. The two pooled regressions include dummies year fixed effects. ${ }^{16}$

The results of the regression are displayed in Table 3.1. Total state government spending was approximately 89 percent private for states without the voter initiative process and 97 percent private for initiative states in the 1980 regression. This indicates that spending was about 8 percent more interest-group oriented in states in which the voter initiative process is available.

\footnotetext{
${ }^{15}$ Feenberg and Rosen (1985) provided estimates of the effective average tax rate on sales and income for 1980. The National Center for Higher Education Management Systems estimates the effective average tax rate on sales and income tax for 1990 and 2000.

${ }^{16}$ Alaska is excluded in all years due to the significant revenues from severance taxes on oil and the lack of individual income and sales taxes. New Hampshire is excluded in 1980 and Nevada is excluded in 1990 due to missing data.
} 
Table 3.1: Total State Government Expenditure Estimates

\begin{tabular}{|c|c|c|c|}
\hline \multirow[t]{2}{*}{ Independent Variable } & \multicolumn{3}{|c|}{ Coefficient Estimates } \\
\hline & 1980 & $\begin{array}{l}1990 \& 2000 \\
\text { Pooled }\end{array}$ & $\begin{array}{c}\text { 1980, } 1990, \& 2000 \\
\text { Pooled }\end{array}$ \\
\hline Constant & $\begin{array}{l}-5.0344 * \\
(2.8714)\end{array}$ & $\begin{array}{l}-11.2533 * * * \\
(2.3490)\end{array}$ & $\begin{array}{l}-6.2006 * * * \\
(1.6793)\end{array}$ \\
\hline Tax Share $\left(T_{i}\right)$ & $\begin{array}{c}-0.1828 * * * \\
(0.0555)\end{array}$ & $\begin{array}{c}-0.3774 * * * \\
(0.0502)\end{array}$ & $\begin{array}{c}-0.2760 * * * \\
(0.0339)\end{array}$ \\
\hline Initiative*Tax Share $\left(I * T_{i}\right)$ & $\begin{array}{l}0.0852^{*} \\
(0.0488)\end{array}$ & $\begin{array}{l}0.0867 * \\
(0.0463)\end{array}$ & $\begin{array}{c}0.0992 * * * \\
(0.0280)\end{array}$ \\
\hline Population $(N)$ & $\begin{array}{l}0.7259 * * * \\
(0.6832)\end{array}$ & $\begin{array}{c}0.5649 * * * \\
(0.0543)\end{array}$ & $\begin{array}{c}0.6473 * * * \\
(0.0401)\end{array}$ \\
\hline Initiative*Population $(I * N)$ & $\begin{array}{l}0.1499 * \\
(0.0872)\end{array}$ & $\begin{array}{l}0.1417 * \\
(0.0787)\end{array}$ & $\begin{array}{c}0.1664 * * * \\
(0.0484)\end{array}$ \\
\hline Income $\left(Y_{i}\right)$ & $\begin{array}{c}0.6531 * * * \\
(0.2230)\end{array}$ & $\begin{array}{c}0.8855 * * * \\
(0.1522)\end{array}$ & $\begin{array}{c}0.6296 * * * \\
(0.1122)\end{array}$ \\
\hline Population Density ( $D E N$ ) & $\begin{array}{c}0.0341 \\
(0.0339)\end{array}$ & $\begin{array}{l}-0.0169 \\
(0.0212)\end{array}$ & $\begin{array}{c}0.0127 * * * \\
(0.0172)\end{array}$ \\
\hline Median Age $(A G E)$ & $\begin{array}{l}-0.5474 \\
(0.5194)\end{array}$ & $\begin{array}{l}0.5361^{*} \\
(0.3204)\end{array}$ & $\begin{array}{l}0.0366 \\
(0.2615)\end{array}$ \\
\hline$\%$ Non-white $(N W)$ & $\begin{array}{l}-0.0087 \\
(0.0306)\end{array}$ & $\begin{array}{c}0.0174 \\
(0.0262)\end{array}$ & $\begin{array}{c}0.0078 \\
(0.0200)\end{array}$ \\
\hline $\begin{array}{l}\text { \# Local Governments } \\
\text { (sq. mi.) (LOCAL ) }\end{array}$ & $\begin{array}{l}-0.0524 \\
(0.0332)\end{array}$ & $\begin{array}{l}-0.0271 \\
(0.2133)\end{array}$ & $\begin{array}{c}-0.0385^{* *} \\
(0.0180)\end{array}$ \\
\hline Pop. Growth Rate (CPOP) & $\begin{array}{l}-0.0364 \\
(0.0250)\end{array}$ & $\begin{array}{l}-0.0423 * \\
(0.0238)\end{array}$ & $\begin{array}{c}-0.0370^{* *} \\
(0.0161)\end{array}$ \\
\hline Year 1990 (NINETY) & - & $\begin{array}{c}-0.5872 * * * \\
(0.0516)\end{array}$ & $\begin{array}{l}-0.6817 * * * \\
(0.0418)\end{array}$ \\
\hline Year 1980 (EIGHTY) & - & - & $\begin{array}{c}-0.8191 * * * \\
(.01374)\end{array}$ \\
\hline$\gamma_{N} \sim$ Non-Initiative States & 0.8882 & 0.9073 & 0.8941 \\
\hline$\gamma_{I} \sim$ Initiative States & 0.9706 & 0.9962 & 0.9885 \\
\hline Adjusted R-Squared & 0.9758 & 0.9840 & 0.9826 \\
\hline F-statistic & 190.23 & 538.26 & 677.64 \\
\hline Observations & 48 & 97 & 145 \\
\hline
\end{tabular}


The pooled regression for 1990 and 2000 shows that total state government spending was about 91 percent private in states in which the voter initiative process is unavailable while the spending in voter initiative states was almost purely private. Spending was again approximately 8 percent more private in voter initiative states. Finally, the pooled regression for 1980, 1990, and 2000 displays that about 89 percent of total state government spending was private in states that lack the voter initiative process. Voter initiative state spending was around 99 percent private. Once again, a greater degree of private spending is found in the voter initiative states. Total state government spending is approximately 9 percent higher in voter initiative states.

The estimates for the publicness of total state government spending are calculated using nonlinear combinations of the parameters for tax share elasticity and population elasticity. Therefore a Monte Carlo simulation is performed to ensure that the calculated values are significantly different from one and that the publicness estimates are significantly different between voter initiative states and states in which the voter initiative process is unavailable. A simulation of 3000 such calculations was generated using the parameter estimates in conjunction with the covariance matrix of the estimates. Table 3.2 shows the results from this Monte Carlo simulation. The point estimates differ slightly from the mean estimates from the empirical distribution because the covariance between the coefficient estimates makes the expected value of the ratio of the coefficient estimates different from the ratio of expected values of each individual coefficient.

The confidence intervals for the measure of publicness in states without the voter initiative process show that the value is significantly less than one. This signifies that total state spending is not a pure private good. However, the confidence intervals for the voter initiative state measure of publicness show the value is not significantly different from one, suggesting 
Table 3.2: Monte Carlo Point Estimates for $\gamma_{N}$ and $\gamma_{I}$, Estimated Mean Differences for $\gamma_{N}$ $\gamma_{I}$, and Confidence Intervals

\begin{tabular}{|c|c|c|c|c|c|}
\hline Regression & & $\begin{array}{c}\text { Point } \\
\text { Estimate }\end{array}$ & $\begin{array}{c}\text { Mean of } \\
\text { Empirical } \\
\text { Distribution }\end{array}$ & $\begin{array}{c}90 \% \\
\text { Confidence } \\
\text { Interval }\end{array}$ & $\begin{array}{c}95 \% \\
\text { Confidence } \\
\text { Interval }\end{array}$ \\
\hline \multirow[t]{3}{*}{1980} & $\gamma_{N}$ & $0.8864 * *$ & 0.8883 & $\begin{array}{c}0.8128 \text { to } \\
0.9547\end{array}$ & $\begin{array}{c}0.7967 \text { to } \\
0.9702\end{array}$ \\
\hline & $\gamma_{I}$ & 0.9703 & 0.9706 & $\begin{array}{c}0.8913 \text { to } \\
1.0454\end{array}$ & $\begin{array}{c}0.8729 \text { to } \\
1.0597\end{array}$ \\
\hline & $\gamma_{N}-\gamma_{I}$ & $-0.0839 *$ & -0.0823 & $\begin{array}{c}-0.1655 \text { to } \\
-0.0017\end{array}$ & $\begin{array}{c}-0.1849 \text { to } \\
0.0128\end{array}$ \\
\hline \multirow[t]{3}{*}{$\begin{array}{c}1990 \& 2000 \\
\text { Pooled }\end{array}$} & $\gamma_{N}$ & $0.9083^{* *}$ & 0.9073 & $\begin{array}{c}0.8449 \text { to } \\
0.9691\end{array}$ & $\begin{array}{c}0.8334 \text { to } \\
0.9806\end{array}$ \\
\hline & $\gamma_{I}$ & 0.9941 & 0.9962 & $\begin{array}{c}0.9210 \text { to } \\
1.0604\end{array}$ & $\begin{array}{c}0.9079 \text { to } \\
1.0721\end{array}$ \\
\hline & $\gamma_{N}-\gamma_{I}$ & $-0.0857^{*}$ & -0.0889 & $\begin{array}{c}-0.1656 \text { to } \\
-0.0006\end{array}$ & $\begin{array}{c}-0.1816 \text { to } \\
0.0177\end{array}$ \\
\hline \multirow[t]{3}{*}{$\begin{array}{c}1980,1990, \& \\
2000 \text { Pooled }\end{array}$} & $\gamma_{N}$ & $0.8938 * *$ & 0.8941 & $\begin{array}{c}0.8497 \text { to } \\
0.9386\end{array}$ & $\begin{array}{c}0.8426 \text { to } \\
0.9474\end{array}$ \\
\hline & $\gamma_{I}$ & 0.9878 & 0.9885 & $\begin{array}{c}0.9431 \text { to } \\
1.0323\end{array}$ & $\begin{array}{c}0.9333 \text { to } \\
1.0400\end{array}$ \\
\hline & $\gamma_{N}-\gamma_{I}$ & $-0.0940 * *$ & -0.0944 & $\begin{array}{c}-0.1417 \text { to } \\
-0.0461\end{array}$ & $\begin{array}{c}-0.1502 \text { to } \\
-0.0366\end{array}$ \\
\hline
\end{tabular}

Asterisks indicate significance as follows: $* *=5 \%$ and $*=10 \%$.

that spending in voter initiative states may even be a pure private good. The confidence intervals for the mean difference show that the publicness of total state government spending is significantly different between voter initiative and non-initiative states at a 90 percent confidence level for both the 1980 regression and the 1980 and 2000 pooled regression. Total state government spending is significantly different at both the 90 percent and the 95 percent confidence level for the 1980, 1990, and 2000 pooled regression.

These results indicate that total state government spending is private to a greater extent in voter initiative states in comparison to states in which the voter initiative process is unavailable. 
This suggests that interest groups may influence a larger percentage of state spending in states that have the voter initiative process. State government spending for legislation sponsored by interest groups will tend to be a private good, as the benefits of the legislation accrues in a rival fashion to the members of the group rather than in a non-rival fashion to society at large. However, this does not necessarily imply that narrow special interest groups have a larger influence in states with the voter initiative process. Voter initiative states have more broad-based citizen groups (Boehmke 2002, 2005) and broad-based citizen groups are more effective at passing voter initiatives (Gerber 1999).

Other interesting results are observable in Table 3.1. The tax share elasticity estimate, $\alpha$ or $\beta_{2}$ in the empirical model, is negative and very significant in all regressions. The estimate is less than one, suggesting that the demand for state government expenditures is price inelastic. The coefficient for the marginal effect of tax share elasticity in voter initiative states is positive and significant. This suggests that demand for state government spending is more price inelastic in voter initiative states. The estimate for population elasticity, $\delta$ or $\beta_{4}$ in the empirical model, is positive and significant for all regressions. The coefficient for the marginal effect of population elasticity for the voter initiative states is also positive and significant. The income elasticity estimate, $\lambda$ or $\beta_{6}$ in the empirical model, is positive and significant in every regression. The coefficient suggests that the demand for state government spending is income inelastic as the value is less than one.

The remaining five independent variables were included because previous literature using the median voter demand model incorporated the variables. However, their exclusion does not significantly alter the results of the other estimates. Population density is negative in the 1990 and 2000 pooled estimate and positive otherwise. It is significant in the 1980, 1990, and 2000 
pooled regression. Median age and the non-white percentage of the population are both negative in the 1980 cross section regression and positive otherwise. They are insignificant with the exception of median age in the 1990 and 2000 pooled estimate. Negative estimates are found for the number of local governments per square mile and the population growth rate for all estimates. Both are significant in the 1980, 1990, and 2000 pooled regression while the population growth estimate is significant in the 1990 and 2000 pooled estimate. The year variables are negative and significant in all cases.

\subsection{Conclusion}

Proponents of the voter initiative argue that political outcomes will be more aligned with the preferences of the median voter when the voter initiative is available. Opponents believe that the voter initiative is subject to abuse by special interest groups. This debate surrounding the primary beneficiaries of the voter initiative has been disputed for over a century. The results of this paper imply that the availability of the voter initiative does not reduce the interest group orientation of state government spending. Total state spending is found to be significantly more of a private good in states in which the voter initiative is available. Interest groups support policies that engage in spending that benefits the interest group. The resulting expenditures are a private good as the benefits accrue directly to the members of the group rather than to the population in general. At the very least, we can refute the idea that interest groups exert less influence over total state expenditures in states in which the voter initiative process is available.

This outcome seems to be consistent with the conclusion of Boehmke $(2002,2005)$. He finds that states with the voter initiative process have larger interest group populations. This occurs due to the increased benefit of interest group mobilization when the option of the voter 
initiative is available. The voter initiative affords interest groups the ability to directly propose changes in policy and to indirectly influence the legislature with the threat of a voter initiative. However we cannot assume that narrow special interest groups are the primary beneficiary of the voter initiative. Boehmke $(2003,2005)$ also finds that broad based citizen groups increase in size relative to narrow special interest groups. This is primarily due to the nature of the voter initiative process. Broad based support is necessary to successfully pass a voter initiative. Therefore, while the interest group orientation of state government spending might increase as a result of the presence of the voter initiative process in a state, it is unclear if it transfers power among different types of interest groups. Nonetheless, the evidence seems to clearly suggest that the voter initiative does not result in a reduction in the interest group orientation of government spending. 


\section{Chapter 4}

\section{The Effect of the Voter Initiative on the Value of State Governmental Offices: Evidence from State Legislative and Gubernatorial Elections}

\subsection{Introduction}

The resurgence of the use of the voter initiative process in U.S. states in the 1970's and its continuously increasing role in the U.S. voting process has resulted in renewed interest in voter initiative research. A significant proportion of the literature has been devoted to the debate concerning the primary beneficiaries of the voter initiative process. The focus of the debate centers largely on whether special interest groups or the median voter benefit most from the availability of the voter initiative. While the state legislature is generally regarded as the loser in terms of relinquishing decision making authority when the voter initiative is available, there has been little investigation into the degree to which the decision making power of the state legislature is decreased (if in fact the state legislature sustains any loss in power). Additionally, the impact on the decision making power of the state executive branch has been largely excluded from the discussion.

Matsusaka (2005c) explores the effects of the voter initiative on the relative power of the median voter, legislative branch, and executive branch in U.S. states. He uses a simple model that employs single-peaked preferences to examine policy outcomes. The model shows that the legislative branch does cede decision making power to voters when the voter initiative process is available. However, there is no theoretical evidence to suggest that the legislature or the executive branch will gain power relative to one another. While the voter initiative affords the governor the opportunity to bypass the legislature and propose laws through a direct vote, it also allows the general public to propose laws that can avoid the governor's veto. The theory does 
not allow us to determine the exact impact of the voter initiative on the decision making power of the legislative branch or the executive branch.

The power of a politician lies in their ability to influence policy decisions. While it is very difficult to measure the power of a political office, campaign spending can serve as a proxy measure. While many factors (perhaps most importantly population) influence campaign spending, it is expected that candidates and their campaign contributors will spend more money to gain election to a more powerful position other things constant. Palda (1992) finds that a higher degree of power induces increased spending in gubernatorial elections.

This paper evaluates the effect of the voter initiative on the power of the state legislative and executive branch by examining the amount of money that candidates spend in state elections. Total election cycle spending is estimated for state legislative elections based on an empirical specification by Hogan (2001). An empirical specification by Lott, Jr. (2000) is used to estimate total election cycle spending by U.S. state candidates for gubernatorial seats. It is expected that candidates will alter their spending accordingly if the availability of the voter initiative affects the power of an office. If the voter initiative damages the power of the office, we would expect to see lower spending in voter initiative states other things constant.

Section II of this paper discusses the possible advantages and disadvantages that the state legislative branch and executive branch face with the availability of the voter initiative. Section III examines campaign spending in U.S. state legislative elections and discusses the results for the U.S. legislature. Section IV discusses expenditures in U.S. state gubernatorial elections and presents the results for the executive branch. The effect of the voter initiative on the relative shift of power between the legislative branch and the executive branch is discussed in Section V. Section VI concludes. 


\subsection{The Effect of the Voter Initiative on Relative Power}

Much of the existing voter initiative literature has examined the beneficiaries of the voter initiative process and the corresponding loss in power sustained by the legislature. Since the voter initiative allows voters to break the monopoly that the legislature holds on the creation of laws, it seems obvious that the legislature will in fact lose power relative to the voters when the voter initiative is available. However, the extent of this loss has yet to be empirically investigated. Additionally, the vast majority of the literature fails to account for the role of the executive branch in law making and ignores the effects of the voter initiative process on the executive branch in general.

Matsusaka (2005c) provides the first attempt to examine the effects of the voter initiative on the relative power of the median voter, the legislature, and the executive branch. He uses a simple model similar to Gerber (1996) and Matsusaka and McCarty (2001) in which all actors have single-peaked preferences. The median voter's ideal policy preference (V), the legislature's ideal policy preferences (L), and the governor's ideal policy preference $(\mathrm{G})$ are points along the real line. The policy $(\mathrm{x})$ is a point on the real line. A game between the three participants determines the equilibrium policy $\left(\mathrm{x}^{*}\right)$ along the real line.

This model follows typical convention and ignores the idea that voters play a role in the law making process by electing their government officials. ${ }^{1}$ When this is the case, the median

\footnotetext{
${ }^{1}$ While the legislature and the governor are elected by the voters, Matsusaka (2005) notes that the preferences of the median voter in the state may not coincide with the preferences of the legislature as a whole. State legislators are elected in district elections and typically represent the median voter of the district. Gilligan and Matsusaka (2001), Bradbury and Crain (2001), and Baqir (2002) discuss this issue.
} 
voter and the governor are excluded from the law making process in the absence of the voter initiative. In this case, the legislature is able to select their ideal policy preference $\left(\mathrm{x}^{*}=\mathrm{L}\right){ }^{2}$

However, the median voter and the governor can directly affect a policy decision when the voter initiative is available. While there are several different scenarios and preference orders that may be considered, the evaluation of two potential situations displays the possible effects of the voter initiative on the relative power of the three players. One possible situation is displayed in Figure 4.1(a). In this case, $\mathrm{L}<\mathrm{V}<\mathrm{G}$. The availability of the voter initiative in this situation allows the voters or the governor to propose a policy that is better aligned with their preferences. If the status quo has been determined by the legislature $\left(\mathrm{x}^{*}=\mathrm{L}\right)$, the voters will favor a voter initiative placing the policy closer to their true preference. This policy could be proposed by either the voters or the governor. ${ }^{3}$ The measure would be approved by voters if the voter initiative was placed on the ballot. Additionally, the legislature might preemptively enact legislation that voters prefer to avoid a voter initiative that could push policy farther from the preferences of the legislature. ${ }^{4}$ When the situation in Figure 4.1 (a) exists, both voters and the governor stand to gain when the voter initiative process is available while the legislature loses power. Any policy that prevails can benefit the voter and the governor. At the very least, the voter initiative cannot harm either the voter or the governor in this situation. ${ }^{5}$

\footnotetext{
${ }^{2}$ This simple model ignores gubernatorial veto power. While the governors of all states except for North Carolina have some type of veto power, the passage of a voter initiative avoids the governor's veto powers.

${ }^{3}$ Governors are able to propose voter initiatives due to their status. Arnold Schwarzanegger is an excellent example of a governor who uses the voter initiative process to their advantage when possible.

${ }^{4}$ Gerber $(1996,1999)$ and Matsusaka and McCarty (2001) find that the threat of a voter initiative can cause the state legislature to enact legislation to avoid a less favorable outcome through the voter initiative process. Matsusaka (1995), Gerber and Hug (2001), and Arceneaux (2002) find that the indirect effect of the voter initiative has an impact on policy outcomes.

${ }^{5}$ The governor can still benefit in this situation with incomplete information (Gerber and Lupia, 1995 and McCarty (2001). The voter can be harmed if incomplete information exists (Matsusaka, 2005c).
} 
Figure 4.1: The Effect of the Voter Initiative on the Relative Power of the Legislative Branch, the Executive Branch, and the Median Voter (Matsusaka, 2005)

(a)

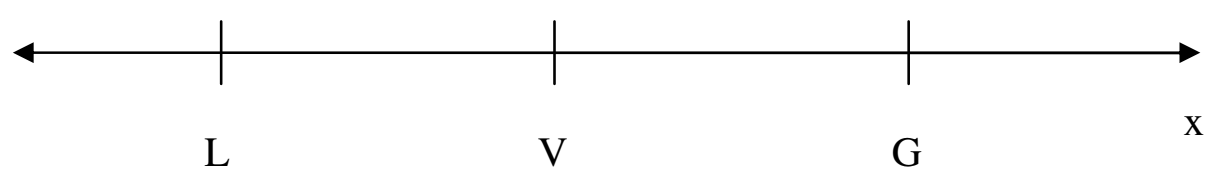

(b)

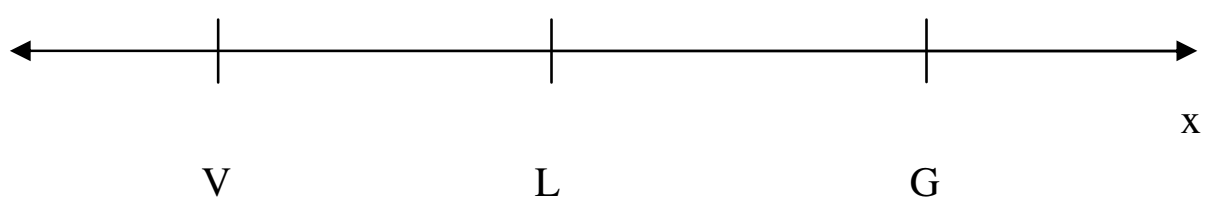

However, a second scenario displayed in Figure 4.1 (b) can have different results. In this case, $\mathrm{V}<\mathrm{L}<\mathrm{G}$. Once again, the availability of the voter initiative allows the voter the opportunity to choose a more ideal policy. Assuming that the status quo policy is determined by the legislature $\left(x^{*}=\mathrm{L}\right)$, voters will prefer a policy further to the left. Once again, the proposition of a voter initiative may lead to preemptive action by the legislature. If the voter initiative were to be placed on the ballot, voters would approve of the measure. However, in this situation, the new policy is farther from the preferred policy of the governor. Additionally, policies that are approved through voter initiatives are exempt from the governor's veto. While the legislature again loses power to the voter in Figure 4.1 (b), the governor can also be harmed by the policy resulting from the voter initiative process. Finally, the voter should benefit from this situation and cannot be harmed at the very least.

According to this basic model, the voters are the one party that cannot be harmed by the presence of the voter initiative. The legislature cannot gain power with the availability of the 
voter initiative process because they would have a monopoly on the production of legislation otherwise. The effect of the voter initiative on the executive branch remains rather ambiguous. The voter initiative can lead to a more favorable outcome for the governor when the policy preferences of the median voter are more aligned with the governor's preferences than the preferences of the legislature, e.g. Figure 4.1 (a). However, the voter initiative can lead to outcomes that are unfavorable to the governor when the preferences of the median voter are more aligned with those of the legislature, e.g. Figure 4.1 (b).

There are a few reasons to believe that the preferences of the median voter in U.S. states will be more aligned with the governor than the legislature. Elections for the state legislature are held in different districts throughout the state. Gilligan and Matsusaka $(2001,2004)$ find that the preferences of the median voter in the state will rarely correspond to the views of the state legislature, as the legislature will generally represent the median views of their districts. Bradbury and Crain (2001) and Baqir (2002) also imply that the views of the state legislature and the state median voter may not necessarily coincide. However, the governor should tend to be more representative of the state median voter because the governor is chosen in a statewide election (Matsusaka, 2005c).

While theory and observation can guide our analysis of the effects of the voter initiative on the relative power of the median voter, the legislature, and the governor, the question has yet to be investigated empirically. This paper attempts to examine this issue by estimating total election cycle spending by candidates for both state legislative and state gubernatorial offices. This affords the opportunity to examine the effects of the voter initiative on the power of the candidates through their own eyes. If the availability of the voter initiative decreases the power of state legislators or state governors, we would expect to find that candidates in voter initiative 
states spend less in election campaigns after controlling for other factors. The following sections provide separate analysis of both state legislative election cycle expenditures and state gubernatorial election cycle expenditures.

\subsection{State Legislative Election Cycle Spending}

In order to evaluate the effect of the voter initiative on the power of the state legislature, this paper will estimate per capita total election cycle spending. Each observation consists of the aggregate spending for all candidates for a state legislative seat in a given district. This measure is used in order to capture the full value of the office. Candidates are aware of the availability of the voter initiative process in their state and should spend accordingly if the voter initiative does affect the power of the legislature. If the voter initiative does in fact reduce the power of the legislature, campaign expenditures are expected to be lower in states where the voter initiative is available. This analysis controls for population in the independent variable because of the existence of a large variation in spending according to district population. Gierzynski and Breaux (1991) and Hogan and Hamm (1998) note that population is in fact one of the most important explanatory factors in legislative campaign spending.

Several previous studies have examined state legislative election spending. Moncrief (1992, 1998) and Hogan (2000) examine state legislative campaign spending at the candidatelevel. Hogan and Hamm (1998) and Hogan (1999) investigate state legislative campaign spending at the district-level. This paper investigates candidate spending aggregated by district and employs a specification similar to those mentioned above. However, this study solely examines open seat elections in order to eliminate the wide variation in spending that occurs when an incumbent is involved in the election. Gierzynski and Breaux (1991) and Moncrief 
(1998) show that incumbents outspend their opponents on a regular basis. Additionally, Ansolabehere and Gerber (1994) find that incumbents spend money on additional factors that are not directly related to the election campaign. The exclusion of elections in which an incumbent is present also excludes the need to account for any type of leadership position or other significant status that an incumbent may obtain in the legislature. These types of incumbents will often benefit from the ability to raise more money because of their status.

In order to estimate the per capita total election cycle spending in open seat elections for state legislative seats, this study includes several independent variables specific to the district and the state in which the election took place. The number of candidates is included as a control variable to account for some of the competition in the election. It is expected that a race with more candidates would involve higher campaign spending other things constant. This can be the result of higher primary spending. Breaux and Gierzynski (1991) find that primary spending can be quite high, particularly in states that are dominated by one party.

The other independent variables account for differences between states that may have an impact on campaign spending. One important factor in campaign spending is the level of professionalism that exists in the state legislature (Squire, 1992; Hogan, 2000, 2001). Members of a state legislature with a high degree of professionalism have more power to influence policy decisions. Additionally, a higher level of professionalism also corresponds with higher salaries and other benefits. Because the level of professionalism varies widely across states, it is expected that legislative professionalism will affect the amount of money that candidates are 
willing to spend in order to become elected. An index developed by Squire (1992) and expanded by King (2000) is used in order to measure legislative professionalism. ${ }^{6}$

Another essential key to the explanation of spending involves campaign finance regulations. While the debate over the effectiveness of campaign finance regulations continues, little empirical evidence exists to support either side. ${ }^{7}$ Hogan (2000) shows that campaign finance regulations did in fact reduce campaign expenditures in state legislative elections in 1994. This study follows Hogan (2000) and categorizes states into three different groups based on the severity of finance laws in 2000 . Two dummy variables are used in order to evaluate the effect of the regulations. The first variable consists of the states in which public funding is available to all candidates. The second variable consists of states in which labor unions and corporations are not allowed to contribute to campaigns and political action committee donations are limited. The excluded group consists of states in which there are little or no restrictions on campaign contributions ${ }^{8}$. The campaign finance laws are expected to have the same effect on all elections included because only open seat elections are considered. ${ }^{9}$

Building on the previous literature, this analysis also performs a regression that includes state expenditures with the other explanatory variables. Legislators in states that have high levels of expenditure effectively control more resources than legislators in states with smaller

\footnotetext{
${ }^{6}$ Squire (1992) constructs a state index of legislative professionalism based on the length of the legislative session, the salary of legislators, and the staff size. King (2000) updates the index to account for other legislative expenditures.

${ }^{7}$ While the intuitive expectation is that campaign finance laws will restrict campaign spending, studies such as Alexander (1991) argue that laws will do little to curtail the amount of money that is spent in politics.

${ }^{8}$ The vast majority of states fall into the category in which corporation and unions cannot contribute to candidates and the contributions of PACs are limited. California, Illinois, Missouri, New Mexico, Oregon, Utah, and Virginia are coded as states with virtually no restrictions. Maine, Minnesota, and Wisconsin are the only states classified as public funding states because the public funding laws in the states apply to a large number of elections. As explained in Malbin and Gais (1998), Hawaii is not coded as a public funding state because very little candidates ever receive funds.

${ }^{9}$ It is expected that contribution would limit spending for all types of candidates. However, public financing may actually increase the spending of challengers while decreasing the spending of incumbents. Campaign finance should affect all candidates in the same fashion in this examination as the analysis focuses on open seat elections.
} 
expenditures. Due to this, it seems reasonable to assume that candidates would be willing to spend more to gain control of legislative seats in the states with higher expenditures. Lott, Jr. (2000) finds that higher state expenditures result in higher campaign expenditures in both state gubernatorial elections and state senate and house elections.

In order to examine the effect of the voter initiative on campaign spending, a dummy variable is included for voter initiative states. States in which the voter initiative process is unavailable are the excluded group. ${ }^{10}$ States in which the voter initiative process is available differ in the amount of signatures that are required in order to place an initiative on the ballot. ${ }^{11}$ This is accounted for by the inclusion of a signature requirement variable. The percentage signature requirement is included for states with the voter initiative while states that lack the availability of the voter initiative process receive a value of zero. ${ }^{12}$ Year dummy variables are included to account for time fixed effects.

The data for the dependent variable in this analysis consists of the total election cycle spending in state legislative elections for every open seat for the year 2000. This was obtained through the National Institute on Money in State Politics. The data sources are listed in the appendix. Summary statistics are presented in Table 4.1. The results are presented in Table 4.2. Column (a) shows the results of the standard independent variables with the voter initiative

\footnotetext{
${ }^{10}$ Wyoming is not included as a voter initiative state because it has an extremely high signature requirement at $15 \%$. Illinois is not included as a voter initiative state because it is the only state in which a proposal can only be used to alter the organization of the state legislature. This follows the logic of Matsusaka (2004). The inclusion of Wyoming and Illinois does not significantly alter the results.

${ }^{11} 24$ states have a form of the voter initiative at the state level. The signature requirement varies from a low of 3\% to a high of $15 \%$ (Initiative and Referendum Institute). This difference in signature requirements results in substantial differences in the effects of the voter initiative process. It can be very difficult to collect the signatures required for states with high signature requirements.

12 The signature requirement variable follows Matsusaka (2004).
} 
Table 4.1: Descriptive Statistics for Legislative Spending Regression

\begin{tabular}{|l|c|c|c|c|}
\hline \multicolumn{1}{|c|}{ Variable } & Average & $\begin{array}{c}\text { Standard } \\
\text { Deviation }\end{array}$ & $\begin{array}{c}\text { Maximum } \\
\text { Value }\end{array}$ & $\begin{array}{c}\text { Minimum } \\
\text { Value }\end{array}$ \\
\hline $\begin{array}{l}\text { State District Election Cycle } \\
\text { Legislative Spending Per Capita }\end{array}$ & $\$ 2.00$ & $\$ 2.25$ & $\$ 33.22$ & $\$ 0.002$ \\
\hline Per Capita State Expenditures & $\$ 3992.03$ & $\$ 1150.56$ & $\$ 10,543.86$ & $\$ 2,828.68$ \\
\hline State District Population & 70,683 & 104,119 & 846,792 & 7,870 \\
\hline
\end{tabular}

There are 689 observations for per capita state district election cycle legislative spending from the 2000 election cycle. Per capita state expenditures and state district population are for the year 2000.

variable included while (b) displays the inclusion of the signature requirement. Columns (c) and (d) follow suit but include per capita state expenditures as an independent variable.

The results suggest that the availability of the voter initiative does have a significant impact on campaign spending in all cases. Total per capita state district legislator election cycle spending is approximately $\$ 0.60$ cents less in column (a) and $\$ 0.52$ cents less in column (c) when per capita state expenditures are included. The availability of the voter initiative does in fact seem to weaken the power of the state legislature.

The signature requirement affects the operation of the voter initiative process. Because it is more difficult to collect a higher number of signatures, it is expected that the use and the threat of the voter initiative would be stronger in states in which the signature requirement is lower. The results in columns (b) and (d) of Table 2 show that this is in fact the case. As the signature requirement rises, the negative impact of the voter initiative on campaign spending decreases. An F-test was performed and confirmed the joint significance between the voter initiative dummy variable and the signature requirement variable. This signifies that legislators view the voter initiative as more of a threat when the signature requirement is lower.

The other independent variables are also of interest. As expected, a higher number of candidates, a higher degree of legislative professionalism, and higher per capita state 
Table 4.2: Total State District Legislator Election Cycle Spending Per Capita

\begin{tabular}{|c|c|c|c|c|}
\hline \multirow[t]{2}{*}{ Independent Variable } & \multicolumn{4}{|c|}{ Coefficient Estimates (standard errors in parenthesis) } \\
\hline & (a) & (b) & (c) & (d) \\
\hline Voter Initiative & $\begin{array}{c}-\mathbf{- 0 . 6 0 4 7} * * * \\
(0.1759)\end{array}$ & $\begin{array}{l}-1.5733 * * * \\
(0.3970)\end{array}$ & $\begin{array}{l}-0.5173 * * * \\
(0.1721)\end{array}$ & $\begin{array}{c}-1.1917 * * * * \\
(0.3940)\end{array}$ \\
\hline Signature Requirement & $\cdots$ & $\begin{array}{l}\mathbf{0 . 1 4 1 3} * * * \\
(0.0520)\end{array}$ & 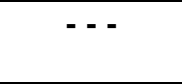 & $\begin{array}{l}0.0978 * \\
(0.0514)\end{array}$ \\
\hline Number of Candidates & $\begin{array}{c}0.3698 * * * \\
(0.0564)\end{array}$ & $\begin{array}{l}0.3763 * * * \\
(0.0562)\end{array}$ & $\begin{array}{c}0.4183 * * * \\
(0.0556)\end{array}$ & $\begin{array}{c}0.4204 * * * \\
(0.0555)\end{array}$ \\
\hline Contribution Limits & $\begin{array}{l}-0.4698 * * \\
(0.2172)\end{array}$ & $\begin{array}{c}-0.4877 * * \\
(0.2163)\end{array}$ & $\begin{array}{c}-0.5210 * * \\
(0.2120)\end{array}$ & $\begin{array}{c}-0.5310 * * \\
(0.2117)\end{array}$ \\
\hline Public Funding & $\begin{array}{l}-0.4593 \\
(0.2894)\end{array}$ & $\begin{array}{c}-0.7595 * * \\
(0.3085)\end{array}$ & $\begin{array}{l}-0.6985 * * * \\
(0.2850)\end{array}$ & $\begin{array}{c}-0.8948 * * * \\
(0.3026)\end{array}$ \\
\hline $\begin{array}{l}\text { Legislative } \\
\text { Professionalism }\end{array}$ & $\begin{array}{l}2.1072 * * * \\
(0.6260)\end{array}$ & $\begin{array}{l}2.1534 * * * \\
(0.6234)\end{array}$ & $\begin{array}{l}1.2477 * * * \\
(0.6272)\end{array}$ & $\begin{array}{l}1.3207 * * \\
(0.6271)\end{array}$ \\
\hline $\begin{array}{l}\text { Per Capita State } \\
\text { Expenditures (thousands) }\end{array}$ & $-\cdots$ & $-\cdots$ & $\begin{array}{l}0.4311 * * * \\
(0.0718)\end{array}$ & $\begin{array}{c}0.4105^{* * *} * \\
(0.0725)\end{array}$ \\
\hline Constant & 1.1414 & 1.1587 & -0.4998 & -0.4093 \\
\hline Adjusted R-Squared & 0.1020 & 0.1103 & 0.1458 & 0.1491 \\
\hline
\end{tabular}

Note: Dependent variable is per capita state district legislative election cycle spending for open seat elections for the year 2000. Standard errors are noted in parenthesis. There are 689 observations. Asterisks indicate significance as follows: $* * *=1 \%, * *=$ $5 \%, *=10 \%$.

expenditures lead to higher levels of campaign spending. The existence of contribution limits and the availability of public funding decrease campaign spending significantly in all regressions with the exception of column (a).

\subsection{State Gubernatorial Election Cycle Spending}

As mentioned previously, the voter initiative has an ambiguous effect on the power of the executive branch. Total per capita election cycle gubernatorial expenditures are estimated in order to examine the issue. Higher campaign spending in states in which the voter initiative is available would suggest that the governor gains power from the voter initiative process. On the 
other hand, lower spending would imply that the voter initiative process decreases executive branch power.

In order to estimate total election cycle spending, this analysis follows a model of campaign expenditure estimates from Lott, Jr. (2000). The study accounts for a number of state specific and election specific factors in order to determine campaign spending. As with the legislative campaign spending estimation, the dependent variable will account for state population by examining gubernatorial campaign spending on a per capita basis. State population accounts for a great deal of the differences in spending between states.

Lott, Jr. (2000) employs two specifications in his estimation. The first specification addresses basic independent election specific variables while the second specification examines differences in elections in greater detail. Per capita state expenditures are the most important determinant of campaign spending according to Lott, Jr. He argues that this is due to the fact state expenditures are the resources that candidates are vying to control. Per capita income and population are also included as candidates are expected to have a greater desire to control richer and larger states. A dummy variable is included to account for states that have split control of the state legislature. It is possible that prospective governors may prefer unified legislatures that are aligned with their political preferences.

Two variables involving the term of the governor are included to account for variability across states. A dummy variable for the maximum number of years that the governor is allowed to serve is included. ${ }^{13}$ It is expected that a position in which candidates can serve for a longer period of time would be more valuable due to the increase in power that the candidate may enjoy

\footnotetext{
${ }^{13} 35$ states limit the governor to a maximum of two consecutive terms, 14 states do not have a term limit for the governor, and Virginia does not allow the governor to serve consecutive terms (The Book of the States).
} 
from spending time in office. Another dummy variable is included to account for the length of term that the governor serves. ${ }^{14}$

In the first specification, two variables are included to account for the conditions of the election. The existence of an incumbent in an election can have a drastic effect on the level of spending, given the clear advantages that incumbents enjoy over challengers. ${ }^{15}$ Higher spending is expected in open seat elections because none of the candidates have the advantage of name recognition and support. A variable is also included to account for the number of candidates involved in the election. Candidates are expected to spend more when there are more challengers.

The second specification includes more variables to account for differences in the elections. A variable is included to account for incumbents and number of candidates in the election as mentioned previously. It is also expected that closer races will involve higher levels of spending. Candidates will generally spend less if they perceive that they will win or lose by a large margin. This is measured with the post-election winning margin. ${ }^{16}$ The three aforementioned variables are included for the general election, the republican primary, and the democratic primary.

Variables are also included to account for the lack of a challenger in both the republican and democratic primary elections. Candidates are expected to spend less when they do not have to compete in a primary election. The percentage differences between the number of republicans and democrats in both the state senate and house are included. Prospective governors may be

\footnotetext{
${ }^{14}$ Governors currently serve four year terms in all states except New Hampshire and Vermont. Arkansas had a two year term until 1986 and Rhode Island had a two year term until 1994 (The Book of the States).

${ }^{15}$ Incumbents enjoy recognition and status benefits over challengers, allowing them access to greater finances. Open seat candidates are also well financed as they have a greater chance to win than challengers. Gierzynski and Breaux (1991) and Moncrief (1998) and other studies show that incumbents and open seat candidates spend more in elections in comparison to challengers.

${ }^{16}$ Candidates generally have an idea of the closeness of the election and spend accordingly. This follows Muth's (1961) rational expectations and is used in Kirchgässner and Meyer Zu Himmern (1997).
} 
willing to spend more when the state legislature is more politically weighted in their favor. Finally, in order to assess the effect of the voter initiative, variables are included for voter initiative states and signature requirement as discussed in the previous section. Year dummy variables are included to account for time fixed effects.

The data sources are listed in the appendix. Summary statistics are presented in Table 4.3. The results are presented in Tables 4.4 and 4.5. Table 4.4 displays the results for the two specifications with the inclusion of the dummy variable for voter initiative states. Table 4.5 shows the results when the signature requirement is also included.

The results in Table 4.4 indicate that the availability of the voter initiative process does in fact decrease spending in gubernatorial contests in both specifications by about forty-seven and fifty cents in columns (a) and (b) respectively. ${ }^{17}$ This implies that the availability of the voter initiative weakens the executive branch as well. While the voter initiative does help the governor to sidestep the legislature in some instances, it seems that the ability of the voter initiative to avoid the governor's veto power more than offsets any other benefits.

Table 4.5 displays the results of the analysis with the signature requirement. While the voter initiative variable is negative, it is no longer significant. An F-Test confirms that the voter initiative variable and the signature requirement variable are jointly insignificant. This may be explained by the dual nature of the effects of the voter initiative on the executive branch. While the analysis implies that the availability of the voter initiative decreases the power of the executive branch overall, it does benefit the executive branch under certain circumstances. The benefits to the executive branch may occur at different levels of the signature requirement, which

\footnotetext{
${ }^{17}$ While the legislative estimates investigated solely open seat elections, the analysis of gubernatorial elections includes incumbent elections as well. This is due to the limited number of observations of gubernatorial elections. However, the regression analysis for gubernatorial spending was performed excluding elections in which an incumbent was present. The primary results of the analysis did not change.
} 
Table 4.3: Descriptive Statistics for Gubernatorial Spending Regressions

\begin{tabular}{|l|c|c|c|c|}
\hline \multicolumn{1}{|c|}{ Variable } & Average & $\begin{array}{c}\text { Standard } \\
\text { Deviation }\end{array}$ & $\begin{array}{c}\text { Maximum } \\
\text { Value }\end{array}$ & $\begin{array}{c}\text { Minimum } \\
\text { Value }\end{array}$ \\
\hline $\begin{array}{l}\text { Total Election Cycle Gubernatorial } \\
\text { Expenditures Per Capita }\end{array}$ & $\$ 2.94$ & $\$ 2.54$ & $\$ 21.12$ & $\$ 0.21$ \\
\hline Per Capita State Expenditures & $\$ 3,267.91$ & $\$ 1,379.75$ & $\$ 13,127.35$ & $\$ 1,587.89$ \\
\hline Per Capita State Income & $\$ 22,930.01$ & $\$ 4,296.47$ & $\$ 39,720.10$ & $\$ 13,955.81$ \\
\hline State Population (thousands) & 4,677 & 5,280 & 32,988 & 446 \\
\hline
\end{tabular}

There are 304 total per capita election cycle gubernatorial expenditures observations from 1980 - 2002. Per capita state expenditures, per capita state income, and state population are from 1980 - 2002. All monetary amounts are in year 2000 dollars.

could account for the joint insignificance of the voter initiative and signature requirement variables.

Additionally, the analysis suggests that the primary determinants of gubernatorial spending are per capita state expenditures and the closeness of the election. Higher expenditures and closer elections lead to higher spending as expected. The number of years that a governor can serve consecutively also plays a role, with governors being more willing to spend when they can serve longer. The number of challengers and the existence of incumbents, while important in the first specification, do not seem to affect spending when the closeness of the election is included.

\subsection{Comparison of the Legislative Branch and the Executive Branch}

The analysis thus far suggests that both the legislative branch and the executive branch lose power when the voter initiative is available. However, the question of the relative shift of power between the two branches of government remains unanswered. As mentioned previously, Matsusaka (2005c) provides rationale that the voter initiative may benefit state governors at the expense of the state legislature. 
Table 4.4: Total Election Cycle Gubernatorial Expenditures Per Capita

\begin{tabular}{|c|c|c|}
\hline & \multicolumn{2}{|c|}{ Coefficient Estimates (standard errors in parenthesis) } \\
\hline & (a) & (b) \\
\hline Voter Initiative & $\begin{array}{c}-\mathbf{- 0 . 4 6 8 4} * \\
(0.2440) \\
\end{array}$ & $\begin{array}{c}-0.5039 * * \\
(0.2451)\end{array}$ \\
\hline Per Capita Income (thousands) & $\begin{array}{l}-0.0260 \\
(0.0406)\end{array}$ & $\begin{array}{l}-0.0226 \\
(0.0394)\end{array}$ \\
\hline $\begin{array}{l}\text { Per Capita State Expenditures } \\
\text { (thousands) }\end{array}$ & $\begin{array}{c}1.1501 * * * \\
(0.0949)\end{array}$ & $\begin{array}{c}1.1094 * * * \\
(0.0999)\end{array}$ \\
\hline Population & $\begin{array}{l}0.0003 * \\
(0.0002)\end{array}$ & $\begin{array}{c}0.0002 \\
(0.0002) \\
\end{array}$ \\
\hline Split Control State Legislature & $\begin{array}{c}0.0397 \\
(0.2894)\end{array}$ & $\begin{array}{c}0.2314 \\
(0.3133)\end{array}$ \\
\hline Maximum Consecutive Years & $\begin{array}{c}0.6159 * * \\
(0.2859)\end{array}$ & $\begin{array}{c}0.5859 * * \\
(0.2856)\end{array}$ \\
\hline Length of Term & $\begin{array}{c}-0.2874 \\
(0.2169)\end{array}$ & $\begin{array}{c}-0.3535 * \\
(0.2136)\end{array}$ \\
\hline No Incumbent & $\begin{array}{c}0.9920 * * * \\
(0.2553)\end{array}$ & -- \\
\hline Total Number of Candidates & $\begin{array}{c}0.3020 * * * \\
(0.0776)\end{array}$ & $-\cdots$ \\
\hline Percent Difference Senate & --- & $\begin{array}{l}-0.0104 \\
(0.0090)\end{array}$ \\
\hline Percent Difference House & --- & $\begin{array}{c}0.0215 \\
(0.0089) \\
\end{array}$ \\
\hline General Incumbent & $-\cdots$ & $\begin{array}{l}-0.6356 \\
(0.4098)\end{array}$ \\
\hline General \# of Candidates & -- & $\begin{array}{l}-0.0336 \\
(0.3169)\end{array}$ \\
\hline General Winning Margin & $-\cdots$ & $\begin{array}{c}-0.0295 * * * \\
(0.0098)\end{array}$ \\
\hline Republican Incumbent & $-\cdots$ & $\begin{array}{c}0.1237 \\
(0.4569) \\
\end{array}$ \\
\hline No Republican Challenger & --- & $\begin{array}{c}1.0515 * * \\
(0.4647)\end{array}$ \\
\hline Republican \# of Candidates & -- & $\begin{array}{c}0.2032 \\
(0.1608) \\
\end{array}$ \\
\hline Republican Winning Margin & $-\cdots$ & $\begin{array}{c}-0.0156 * * * \\
(0.0058)\end{array}$ \\
\hline Democratic Incumbent & $-\cdots$ & $\begin{array}{l}-0.1307 \\
(0.4462)\end{array}$ \\
\hline No Democratic Challenger & -- & $\begin{array}{c}0.1136 \\
(0.4474) \\
\end{array}$ \\
\hline Democratic \# of Candidates & --- & $\begin{array}{c}0.0340 \\
(0.1828)\end{array}$ \\
\hline Democratic Winning Margin & $-\cdots$ & $\begin{array}{c}-0.0120 * * \\
(0.0418)\end{array}$ \\
\hline Constant & $\begin{array}{l}-1.1838 \\
(1.4368)\end{array}$ & $\begin{array}{c}2.0363 \\
(1.7055)\end{array}$ \\
\hline Adjusted R-Squared & 0.4401 & 0.4913 \\
\hline
\end{tabular}

Note: Dependent variable is per capita state election cycle spending by all gubernatorial candidates for $1980-2002$. Standard errors are noted in parenthesis. There are 304 observations for specification (a) and 298 observations for specification (b) due to missing data. Asterisks indicate significance as follows: $* * *=1 \%, * *=5 \%, *=10 \%$. Year dummy variables are not reported. 
Table 4.5: Total Election Cycle Gubernatorial Expenditures Per Capita

\begin{tabular}{|c|c|c|}
\hline \multirow[t]{2}{*}{ Independent Variable } & \multicolumn{2}{|c|}{ Coefficient Estimates (standard errors in parenthesis) } \\
\hline & (a) & (b) \\
\hline Voter Initiative & $\begin{array}{c}-0.5542 \\
(0.5542)\end{array}$ & $\begin{array}{c}-0.6148 \\
(0.5594)\end{array}$ \\
\hline Signature Requirement & $\begin{array}{c}0.0126 \\
(0.0728)\end{array}$ & $\begin{array}{c}0.0164 \\
(0.0741)\end{array}$ \\
\hline Per Capita Income & $\begin{array}{l}-0.0252 \\
(0.0409)\end{array}$ & $\begin{array}{l}-0.0216 \\
(0.0397)\end{array}$ \\
\hline Per Capita State Expenditures & $\begin{array}{c}1.1471 * * * \\
(0.0967)\end{array}$ & $\begin{array}{c}1.1075 * * * \\
(0.1005)\end{array}$ \\
\hline Population & $\begin{array}{l}0.0003 * \\
(0.0002)\end{array}$ & $\begin{array}{c}0.0002 \\
(0.0002) \\
\end{array}$ \\
\hline Split Control State Legislature & $\begin{array}{c}0.0344 \\
(0.2915) \\
\end{array}$ & $\begin{array}{c}0.2242 \\
(0.3155) \\
\end{array}$ \\
\hline Maximum Consecutive Years & $\begin{array}{c}0.6093 * * \\
(0.2889)\end{array}$ & $\begin{array}{c}0.5743 * * \\
(0.2908) \\
\end{array}$ \\
\hline Length of Term & $\begin{array}{l}-0.2848 \\
(0.2178) \\
\end{array}$ & $\begin{array}{l}-0.3501 \\
(0.2145) \\
\end{array}$ \\
\hline No Incumbent & $\begin{array}{c}0.9960 * * * \\
(0.2568)\end{array}$ & --- \\
\hline Total Number of Candidates & $\begin{array}{c}0.3000 * * * \\
(0.0785)\end{array}$ & --- \\
\hline Percent Difference Senate & --- & $\begin{array}{l}-0.0103 \\
(0.0090)\end{array}$ \\
\hline Percent Difference House & --- & $\begin{array}{c}0.0214 * * \\
(0.0089)\end{array}$ \\
\hline General Incumbent & --- & $\begin{array}{c}-0.6351 \\
(0.4106)\end{array}$ \\
\hline General \# of Candidates & --- & $\begin{array}{l}-0.0548 \\
(0.3317)\end{array}$ \\
\hline General Winning Margin & --- & $\begin{array}{c}-0.0294 * * * \\
(0.0098)\end{array}$ \\
\hline Republican Incumbent & --- & $\begin{array}{c}0.1139 \\
(0.4599)\end{array}$ \\
\hline No Republican Challenger & $-\cdots$ & $\begin{array}{c}1.0620 * * \\
(0.4680)\end{array}$ \\
\hline Republican \# of Candidates & --- & $\begin{array}{c}0.2036 \\
(0.1612) \\
\end{array}$ \\
\hline Republican Winning Margin & --- & $\begin{array}{c}-0.0155 * * * \\
(0.0058)\end{array}$ \\
\hline Democratic Incumbent & --- & $\begin{array}{l}-0.1334 \\
(0.4472) \\
\end{array}$ \\
\hline No Democratic Challenger & --- & $\begin{array}{c}0.1189 \\
(0.4489)\end{array}$ \\
\hline Democratic \# of Candidates & -- & $\begin{array}{c}0.0331 \\
(0.1832)\end{array}$ \\
\hline Democratic Winning Margin & --- & $\begin{array}{c}-0.1210 * * \\
(0.0059)\end{array}$ \\
\hline Constant & $\begin{array}{l}-1.1978 \\
(1.4416) \\
\end{array}$ & $\begin{array}{c}2.0490 \\
(1.7096) \\
\end{array}$ \\
\hline Adjusted R-Squared & 0.4381 & 0.4894 \\
\hline
\end{tabular}

Note: Dependent variable is per capita state election cycle spending by all gubernatorial candidates for 1980 - 2002 . Standard errors are noted in parenthesis. There are 304 observations for specification (a) and 298 observations for specification (b) due to missing data. Asterisks indicate significance as follows: $* * *=1 \%, * *=5 \%, *=10 \%$. Year dummy variables are not reported. 
A rough comparison of the effects of the voter initiative on the two branches can be calculated from the results of the analysis in this paper. While the availability of the voter initiative decreases spending in both elections, there is a relatively larger percentage decrease in state legislative spending in comparison to state gubernatorial spending. The average per capita spending for state legislative elections is $\$ 2.00$ in Table 4.1. The voter initiative decreases

spending in legislative elections by about $\$ 0.52$ in Table 4.2 (c). Spending in state legislative elections is reduced by approximately 26\%. The average per capita spending for state gubernatorial spending is $\$ 2.94$ in Table 4.3. Spending is reduced by about $\$ 0.50$ in Table 4.4 (b). The availability of the voter initiative results in a $17 \%$ decrease in spending for gubernatorial candidates.

This analysis certainly does not completely explain the impact of the voter initiative on the relative power between the legislative and executive branches of the government. However, the results are aligned with the rationale presented in Matsusaka (2005c). The availability of the voter initiative has a relatively larger impact on campaign spending for state legislature elections in comparison to state gubernatorial elections. This suggests that the power of the state legislature is reduced to a greater degree.

\subsection{Conclusion}

This paper examines the effects of the voter initiative on per capita election cycle campaign spending in state legislative and gubernatorial elections. The analysis shows that campaign spending is significantly reduced in both state legislative and executive elections when the voter initiative is available. Candidates for state legislative and state gubernatorial office are less willing to spend in order to gain election in states where the voter initiative is available. This 
implies that the voter initiative has a negative impact on the power of both of these branches of the government.

Additionally, the impact of the voter initiative on the relative power of the legislative branch and the executive branch is examined. Spending is reduced by $26 \%$ on average in legislative elections in comparison to a $17 \%$ average reduction in spending in gubernatorial elections. While not an exact measure, it does align with the theoretical rationale in Matsusaka (2005c). It seems more likely that state governors will be more aligned with the state median voter, which should tip the relative balance of power in favor of the state executive branch relative to the legislative branch when the voter initiative is available. 


\section{Chapter 5}

\section{Measuring the Indirect Effect: Voter Initiatives and Legislative Production in U.S. States}

\subsection{Introduction}

The voter initiative is available in some form at the state level in 24 states in the U.S. The availability of the voter initiative process allows citizens to circumvent the legislature in the proposal and passage of legislation. Policy changes occur when a voter initiative is approved and cannot be vetoed by the governor. Previous studies such as Bowler and Donovan (1998) and Matsusaka (2004) indicate that voter initiatives have a large impact on state policy outcomes. Voter initiatives seem to be playing an increasing role in the shaping of public policy. In 2006, 79 voter initiatives appeared on state ballots across the nation and 32 of the voter initiatives were approved by voters. This was the third largest number of voter initiatives to appear in state elections since the first usage of the process in 1902 (Initiative and Referendum Institute).

The passage of legislation through voter initiatives that are placed on ballots is known as the direct effect of the voter initiative. However, the voter initiative process can affect policy outcomes indirectly as well. The threat of a voter initiative can influence the state legislature to enact legislation in order to avoid the passage of a voter initiative. This allows the state legislature to maintain control over the policy outcome. While the policy may not be aligned with the interests of the state legislature, it may avoid a less favorable outcome that could be enacted through the passage of a voter initiative. Gerber $(1996,1999)$ and Matsusaka and McCarty (2001) discuss the indirect effect of the voter initiative. Matsusaka (1995), Gerber (1996, 1999), and Arceneaux (2002) find that the indirect effect of the voter initiative does in fact influence policy outcomes in U.S. States. 
However, there are other possible indirect effects of the voter initiative process. Magleby (1984) and Cronin (1989) argue that the voter initiative process may allow legislators to shirk and avoid taking decisive action on controversial decisions. In these cases, the passage of a voter initiative could act as a substitute for activity in the state legislature.

While previous research has examined the theory and some specific outcomes involving the indirect effect of the voter initiative, the overall impact of the indirect effect on the state legislature has yet to be determined. This paper examines several issues in order to examine the overall effect of the voter initiative on the production of legislation by the state legislature in U.S. states. First the number of bills passed in U.S. states is estimated following a specification by Rogers (2004). If the primary indirect effect of the voter initiative is to cause the state legislature to take preemptive action, we would expect that states in which the voter initiative process is available will enact more legislation controlling for other factors. The number of special sessions called by U.S. states is also examined. States call special sessions in order to deal with numerous issues. If voter initiative states call special sessions more frequently than states in which the voter initiative is unavailable, evidence would be provided to support the notion that state legislatures become more active in the presence of the voter initiative. Finally, the number of gubernatorial vetoes is estimated for U.S. states. This allows us to examine how the governor reacts to the indirect effect of the voter initiative on legislation in U.S. states.

Section II of this paper discusses the theory behind the indirect effect of the voter initiative. Section III examines legislative production in U.S. states and discusses the results for the estimation of the number of bills enacted. Section IV analyzes the situations that result in the formation of a special session in U.S. state legislatures. Section V discusses the estimation of the governor's usage of veto power. Section VI concludes. 


\subsection{The Indirect Effect of the Voter Initiative}

Gerber and Hug (2001) provide a thorough discussion of both the direct and indirect effects of the voter initiative. The direct effects of the voter initiative occur when the voters approve of a voter initiative that has been placed on the ballot. When this is the case, voters immediately and directly affect policy outcomes. These direct effects of the voter initiative are relatively easy to observe. ${ }^{1}$ However, the indirect effects of the voter initiative are not necessarily as simple to recognize. They require some additional discussion in order to identify how they may affect policy outcomes.

Gerber (1996, 1999) discusses the details of the decision making process of the legislature when faced with the possibility of a voter initiative. Legislatures in states in which the voter initiative is available must consider that any legislation that they enact could be challenged with a voter initiative. Additionally, various groups may propose a voter initiative in an attempt to achieve their policy goals. If these voter initiatives are successful, they could lead to the adoption of policies that contrast with the preferences of the legislature. Therefore, legislators may preemptively enact legislation in anticipation of a potential voter initiative that could lead to an adverse outcome. Gerber (1996) models the behavior of the legislature in a sequential game in which there are three players: the legislature, a group that proposes a voter initiative, and the voter. The objective of each of the players is to select the policy that results in the highest utility level.

The legislature is the first player to act and must decide if they should enact legislation to avoid a voter initiative. The proposing groups then decide whether they should propose a voter

\footnotetext{
${ }^{1}$ It is possible that some voter initiatives that are enacted through the ballot would have been enacted by the legislature in the absence of the voter initiative process (Gerber and Hug 2001).
} 
initiative. The game ends if the proposing group does not propose a voter initiative. These actions must take place before the election. Finally, if a voter initiative is placed on the ballot, the voter must decide between the policy that has been enacted by the legislature and the policy proposed in the voter initiative. Gerber assumes that all players have a specific policy preference. $^{2}$ All players in the model also have access to complete information. ${ }^{3}$ The preferences for each player, costs for each player, and the contents of all policies are know by all of the agents. The policy space is restricted as one dimensional. ${ }^{4}$ There are some additional restrictions that are placed on the agents of the game. The legislature is considered as a unitary actor. ${ }^{5}$ Their ideal policy preference is considered to be the policy that they would choose absent the possibility of the voter initiative. The proposing group is also considered to be a unitary actor. $^{6}$ The preferences of the voter are required to be fixed and known to all actors. Finally, the legislature and the voter do not incur costs in the model. ${ }^{7}$ The proposing group does incur rather large costs. They must devote a significant amount of resources in order to place a voter initiative on the ballot.

The game is solved using backward induction. The voter chooses between the policy proposed by the group and the current policy of the legislature. The option that delivers the

\footnotetext{
${ }^{2}$ Gerber (1996) defines the preferences with a utility function and an ideal policy point. Utility functions are restricted as monotonically decreasing from the player's ideal policy point.

${ }^{3}$ The complete information restriction allows the investigation of the decisions of the agents in the model. In reality the actors may not have all of the relevant information available to make a decision. However, the introduction of imperfect information would not allow the understanding of the intuition in the model (Gerber 1996).

${ }^{4} \mathrm{~A}$ one dimensional policy space is logical in this situation because voter initiatives are restricted to a single issue and voters have only two choices (yes or no).

${ }^{5}$ While there may be disagreement between individual legislators, the legislative bodies, or the branches of the government, the groups would choose a policy point in the absence of the voter initiative (Gerber 1996). This assumption allows for the examination of the relationship between the three agents in the model.

${ }^{6}$ It is possible for several competing groups to propose different or even conflicting policies. However, over time the groups tend to split into two groups: one that supports the voter initiative and one that opposes the voter initiative.

${ }^{7}$ While the legislature may incur an opportunity cost of examining one issue over another, they have already decided to evaluate the issue when this model begins. Voter behavior is considered to be costless for simplicity (Gerber 1996).
} 
greatest utility is chosen by the voter. The proposing group encounters a more difficult decision. It would only be reasonable to propose a voter initiative if the benefits of the voter initiative outweighed the benefits of the current policy in addition to the costs of proposing the voter initiative. Additionally, the voter initiative will only be proposed if the group is certain that the voters will approve of the proposed policy. The proposing group will only support a voter initiative if both of the aforementioned conditions exist. If the group decides to propose a voter initiative, they will propose the policy that results in their highest utility. Finally, the legislature is left with a rather simple decision. They will enact legislation in order to avoid a voter initiative if the proposing group chooses to propose a policy that is less desirable than the policy that the legislators can enact. Otherwise the legislature will not take action.

The model provides the framework in which the legislature makes decisions when the voter initiative is available. In the end, the legislature will enact legislation if it provides a greater benefit (or less of a loss in utility) than the possible voter initiative. However, there may be other indirect effects of the voter initiative as well. Magleby (1984) and Cronin (1989) argue that the voter initiative may allow the legislature to avoid making difficult decisions. The legislature may choose inaction as opposed to making an unpopular decision that could hamper their reelection chances. Legislators may allow the voters to decide the outcome of these decisions through a voter initiative. This type of legislative inaction would lead to a reduction in the number of policy decisions made by the legislature.

While a number of recent empirical investigations have indicated that the presence of the voter initiative has significant policy effects, there is little evidence that directly attributes these effects to the indirect effect of the voter initiative. Matsusaka $(1995,2004)$ finds that states in which the voter initiative is available have lower levels of spending and taxes, more user fees, 
and more local spending in comparison to states in which the voter initiative process is unavailable. Many of these policy effects occurred without the direct proposal of a voter initiative. Gerber $(1996,1999)$ provides the most compelling evidence for the link between the indirect effects of the voter initiative and policy changes. Gerber (1996) examines the issue of parental notification and consent for abortions in U.S. states. The median voter's preferences for the issue are estimated using survey data. Gerber finds that states in which the voter initiative process is available are more likely to require parental notification of abortion in minors, which is preferred by a majority in opinion polls. Arceneaux (2002) finds similar results using more recent survey data. These provide excellent examples of the indirect effects of the voter initiative because policies are different in states in which the voter initiative is available even though the issue of parental notification and consent of abortions has not appeared as a voter initiative. Gerber (1999) finds similar results for the death penalty in U.S. states. Once again, the median voter's preferences are estimated through survey data. Voter initiative states are more likely to have policies that the median voter prefers although voter initiatives were not used to achieve the policy directly.

This study contributes to the literature by examining the overall indirect impact of the voter initiative on legislative production in U.S. states. In theory, the voter initiative causes the legislature to produce more legislation in order to avoid unfavorable voter initiatives while possibly taking less action in order to avoid decisions on contentious issues. The goal of this paper is to determine which of these effects is dominant (if the voter initiative does have a significant indirect effect). This is done by estimating the number of bills enacted and the number of special sessions called by state legislators. The usage of the governor's veto is also 
examined in order to determine how the indirect effect of the voter initiative affects the governor.

\subsection{Measuring Legislative Production}

In order to assess the impact of the voter initiative on the production of legislation in U.S. states, this section of the paper specifies an empirical estimation of the number of bills enacted by U.S. state legislatures. Studies in the past have examined the production of legislation primarily in order to examine the impact of divided government. The vast majority of the research in the area focuses on the federal government. Mayhew (1991), Kelly (1993), and Howell, Adler, Cameron, and Rieman (2000) examine the production of legislative at the national level. The studies examine legislation of different levels of significance (in an attempt to include only important legislation). Rogers (2004) also estimates legislative production in order to examine the issue of divided government. This study does not limit the analysis to significant legislation. ${ }^{8}$

This estimation generally follows the empirical specification of Rogers (2004). However, Rogers examines state legislation that has been enacted from the chamber in which it originated. This study will examine the number of bills enacted at the U.S. state level. ${ }^{9}$ A number of variables are included to account for differences in both states and state legislative processes. The log of population is included as a proxy of the demand for legislation. The length of the legislative session varies across states and tends to have a large impact on the number of bills that are enacted in the session. A variable that measures the actual number of

\footnotetext{
${ }^{8}$ Rogers argues that several minor laws may combine to have a significant impact on policy. Additionally, the task of qualifying legislation as significant is difficult and subjective.

${ }^{9}$ The dependent variable in Rogers (2004) is the number of bills enacted by a state legislature by chamber of origination. This is done in order to assess the differences between divided branch government and divided party government. Data on the chamber of origin is not available for many states. The primary objective of this paper is to examine the effects of the voter initiative. This requires the analysis of both voter initiative and non-initiative states. For this reason, this study examines the number of bills enacted at the state level.
} 
legislative business days in a session is included. It is expected that large population and longer legislative sessions result in greater legislative production. There are two clauses that some states employ in an attempt to regulate legislation. Some states have a single subject clause that limits each bill to one particular topic. ${ }^{10}$ Additionally, some states utilize an origination clause that requires all revenue bills to originate in the house chamber of the state legislature. ${ }^{11}$ Two dummy variables are used to control for these clauses. States in which the clauses do not exist are the excluded group. The revenue bill of origination clause should decrease legislative production. However, the effect of the single subject clause is somewhat ambiguous. While it may increase the number of bills enacted as larger bills must be separated into individual bills, the clause also decreases logrolling opportunities among legislators, which may decrease the number of bills enacted (Rogers 2002).

A dummy variable is included to account for sessions in which the legislature was divided. This occurs when the house and senate of a state legislature consist of a majority of opposite political parties. Divided branch government is included by incorporating a dummy variable that takes the value of one if the governor is the opposite political party of a unified legislature. The expectation is that divided government would decrease the production of legislation. ${ }^{12}$ A final dummy variable accounts for the party of the governor in the state. This tests if democratic governors allow more legislation to pass than republican governors. The dummy variable takes a value of one if the state governor is a republican. Legislator salary is also accounted for in the analysis.

\footnotetext{
${ }^{10} 41$ states have a constitutional provision requiring a single subject for legislation.

1118 states have a constitutional provision requiring revenue bills to originate in the house.

${ }^{12}$ Rogers (2004) finds that divided legislative government significantly reduces legislative production while divided branch government does not have a significant effect.
} 
The remaining variables describe the specific state legislatures and are also adapted from Rogers (2004). The logged percentage of republican legislators in both the state house and senate are included to examine the impact that republican legislators have on legislative production. $^{13}$ Legislative turnover may affect legislative production. The percentage of new legislators that join both the house and the senate from the previous year's election are included. Legislators may gain information, skills, and relationships though their experiences in the legislature. Therefore, it is expected that a higher percentage of new legislators will lead to less legislative production. A greater number of legislators in both the state house and senate may lead to more legislative production (Rogers 2002). The numbers of house and senate legislators are included to account for these possible effects. Legislative staff may help to facilitate the production of legislation. The average number of staff members available to house and senate legislators is included. Finally, variables are included to account for the number of house standing committees, senate standing committees, and joint standing committees. These are generally believed to generate legislative production. ${ }^{14}$

In order to examine the effect of the voter initiative on the number of bills enacted, a dummy variable is included. States in which the voter initiative process is available receive a value of one while states that lack the voter initiative process are the excluded group. ${ }^{15}$ States in which the voter initiative process is available differ in the amount of signatures that are required

\footnotetext{
${ }^{13}$ The percentage of republican legislators is logged in order to account for the possibility that an increasing number of republican legislators should have an increasing effect on legislative production. The inclusion of the percentage of republicans does not alter results (Rogers 2004).

${ }^{14}$ Committees are thought to decrease the incentives to free ride (Crain and Tollison, 1982, Rogers, 2002), help legislators to gain specialized knowledge (Gilligan and Krehbiel 1987, Krehbiel 1998), and assist legislators in achieving personal goals (Mayhew 1974).

${ }^{15}$ Wyoming is not included as a voter initiative state because it has an extremely high signature requirement at $15 \%$. Illinois is not included as a voter initiative state because it is the only state in which a proposal can only be used to alter the organization of the state legislature. This follows the logic of Matsusaka (2004). The inclusion of Wyoming and Illinois does not significantly alter the results.
} 
in order to place a voter initiative on the ballot. ${ }^{16}$ This is accounted for by the inclusion of a signature requirement variable. The percentage signature requirement is included for states with the voter initiative while states in which the voter initiative process is unavailable receive a value of zero. ${ }^{17}$ Year dummy variables are included to account for time fixed effects.

The dependent variable is the number of bills enacted by U.S. states during the regular legislative session in odd years from $1981-2001 .^{18}$ The data sources are listed in the appendix. Summary statistics are presented in Table 5.1. The results of the analysis are presented in Table 5.2. The analysis suggests that the availability of the voter initiative does have a significant impact on the production of legislation in U.S. states. Column (a) of Table 5.2 shows that states with the voter initiative enact about 97 more bills per year than states that lack the voter initiative process.

The signature requirement affects the use of the voter initiative process. It is expected that the use and threat of the voter initiative would be weaker when the signature requirement is higher because it is more difficult to acquire a larger number of signatures. Column (a) of Table 5.2 shows that the signature requirement does significantly affect the production of legislation. This primary result is robust to different model specifications. The voter initiative has a larger impact on the number of bills enacted when the signature requirement is lower. A lower signature requirement coincides with the passage of more legislation. An F-test was performed and confirmed the joint significance between the voter initiative variable and the signature

\footnotetext{
${ }^{16} 24$ states have a form of the voter initiative at the state level. The signature requirement varies from a low of $3 \%$ to a high of $15 \%$ (Initiative and Referendum Institute). This difference in signature requirements results in substantial differences in the effects of the voter initiative process. It can be very difficult to collect the signatures required for states with high signature requirements.

${ }^{17}$ The signature requirement variable follows Matsusaka (2004).

${ }^{18}$ The Book of the States reported data for odd years only until 1999.
} 


\section{Table 5.1: Descriptive Statistics}

\begin{tabular}{|l|c|c|c|c|}
\hline \multicolumn{1}{|c|}{ Variable } & Average & $\begin{array}{c}\text { Standard } \\
\text { Deviation }\end{array}$ & $\begin{array}{c}\text { Maximum } \\
\text { Value }\end{array}$ & $\begin{array}{c}\text { Minimum } \\
\text { Value }\end{array}$ \\
\hline Number of Bills Enacted (per year) & 484.42 & 352.76 & 3,068 & 34 \\
\hline Gubernatorial Vetoes & 24.92 & 49.72 & 465 & 0 \\
\hline Number of Special Sessions & 0.83 & 1.09 & 7 & 416 \\
\hline State Population (in thousands) & 5,101 & 5,513 & 34,533 & 372 \\
\hline Session Length & 79.71 & 58.18 & 731 & 0 \\
\hline House Standing Committees & 19.23 & 10.08 & 59 & 0 \\
\hline Senate Standing Committees & 14.83 & 6.56 & 38 & 73 \\
\hline Joint Standing Committees & 2.77 & 5.85 & 40 & 400 \\
\hline House Legislators & 111.30 & 55.20 & 20 & 67 \\
\hline Senate Legislators & 39.79 & 10.55 & 3 & 0 \\
\hline House Staff & 1.07 & 0.75 & 3 & 0 \\
\hline Senate Staff & 1.17 & 0.68 & $\$ 99,000$ & 0 \\
\hline Salary & 0.61 & 0.84 & 5 & 0 \\
\hline Number of Natural Disasters & $\$ 18,329.67$ & & \\
\hline
\end{tabular}

The data are for U.S. States from 1981 - 2001 (odd years only due to the data available in The Book of the States). All monetary amounts are in year 2000 dollars.

requirement variable. This signals that state legislators are more responsive to the threat of the voter initiative when the signature requirement is lower.

The results suggest that the indirect effect of the voter initiative does in fact exist as states with the voter initiative enact more legislation. Additionally, the number of bills that are enacted in response to the threat of a voter initiative seem to far outweigh any decrease in legislation that might occur when the legislature does not act on controversial decisions. Some other independent variables are also of interest. As expected, a higher population and a longer session length result in a significantly greater amount of legislation. Additionally, single subject clauses for bills and revenue bill origination clauses significantly decrease the number of bills enacted.

\subsection{Special Sessions}


Table 5.2: Number of Bills Enacted

\begin{tabular}{|c|c|c|}
\hline \multirow{2}{*}{ Independent Variable } & \multicolumn{2}{|c|}{ Coefficient Estimates (standard errors are in parenthesis) } \\
\hline & (a) & (b) \\
\hline Voter Initiative & $\begin{array}{c}97.02 * * * * \\
(33.01)\end{array}$ & $\begin{array}{c}383.39 * * * \\
(75.27)\end{array}$ \\
\hline Signature Requirement & $-\cdots$ & $\begin{array}{c}-40.36 * * * \\
(9.57)\end{array}$ \\
\hline Population $(\log )$ & $\begin{array}{c}188.03 * * * \\
(23.42)\end{array}$ & $\begin{array}{c}201.96 \text { *** } \\
(23.21)\end{array}$ \\
\hline Session Length & $\begin{array}{c}1.004 * * * \\
(0.29)\end{array}$ & $\begin{array}{c}0.7492 * * \\
(0.2899)\end{array}$ \\
\hline Bill Single Subject Clause & $\begin{array}{c}-181.70 * * * \\
(54.53)\end{array}$ & $\begin{array}{c}-234.29 * * * \\
(54.94)\end{array}$ \\
\hline Revenue Bill Origination Clause & $\begin{array}{c}-63.72 * \\
(34.14)\end{array}$ & $\begin{array}{c}-69.74 * * \\
(33.52)\end{array}$ \\
\hline Divided Legislature & \begin{tabular}{|l}
-33.45 \\
$(43.13)$ \\
\end{tabular} & $\begin{array}{l}-24.41 \\
(42.37) \\
\end{array}$ \\
\hline Opposite Party Governor & $\begin{array}{c}4.77 \\
(35.47)\end{array}$ & $\begin{array}{c}14.19 \\
(34.87)\end{array}$ \\
\hline Republican Governor & $\begin{array}{c}13.15 \\
(31.37) \\
\end{array}$ & $\begin{array}{c}6.51 \\
(30.81) \\
\end{array}$ \\
\hline House Republicans (\% log) & $\begin{array}{l}-16.02 \\
(57.36)\end{array}$ & $\begin{array}{l}-67.85 \\
(57.60)\end{array}$ \\
\hline Senate Republicans $(\% \log )$ & $\begin{array}{c}-91.82 * \\
(50.83)\end{array}$ & $\begin{array}{l}-58.75 \\
(50.48)\end{array}$ \\
\hline House Turnover (\%) & $\begin{array}{c}0.2828 \\
(1.89) \\
\end{array}$ & $\begin{array}{c}1.22 \\
(1.87)\end{array}$ \\
\hline Senate Turnover (\%) & $\begin{array}{l}-1.54 \\
(1.75) \\
\end{array}$ & $\begin{array}{l}-1.86 \\
(1.72) \\
\end{array}$ \\
\hline House Standing Committees & $\begin{array}{c}-10.89 * * * \\
(2.57) \\
\end{array}$ & $\begin{array}{c}-10.95 * * * \\
(2.52) \\
\end{array}$ \\
\hline Senate Standing Committees & $\begin{array}{c}4.70 \\
(3.68)\end{array}$ & $\begin{array}{c}5.87 \\
(3.62)\end{array}$ \\
\hline Joint Standing Committees & $\begin{array}{l}-6.71 * \\
(3.73)\end{array}$ & $\begin{array}{l}-7.14 * \\
(3.66)\end{array}$ \\
\hline Number of House Legislators & $\begin{array}{c}-0.1268 \\
(0.3458) \\
\end{array}$ & $\begin{array}{c}-0.3726 \\
(0.34) \\
\end{array}$ \\
\hline Number of Senate Legislators & $\begin{array}{c}0.5752 \\
(1.63)\end{array}$ & $\begin{array}{l}-1.04 \\
(1.65)\end{array}$ \\
\hline House Staff & $\begin{array}{c}66.14 * * \\
(32.13) \\
\end{array}$ & $\begin{array}{l}60.14 * \\
(31.56) \\
\end{array}$ \\
\hline Senate Staff & $\begin{array}{l}-47.60 \\
(34.32) \\
\end{array}$ & $\begin{array}{c}-46.27 \\
(33.67) \\
\end{array}$ \\
\hline Salary (thousands) & $\begin{array}{c}-5.10 * * * \\
(1.20)\end{array}$ & $\begin{array}{c}-5.10 * * * \\
(1.10)\end{array}$ \\
\hline Constant & $\begin{array}{r}-1610.46 \\
(338.89) \\
\end{array}$ & $\begin{array}{l}-1599.95 \\
(332.49)\end{array}$ \\
\hline Adjusted R-Squared & 0.2630 & 0.2906 \\
\hline
\end{tabular}

Note: Dependent variable is the number of bills enacted in U.S. States during the regular legislative session every other year from 1981 - 2001 (due to the information available in the Book of States). Standard errors are noted in parenthesis. There are 461 observations. Asterisks indicate significance as follows: $* * *=1 \%, * *=5 \%, *=10 \%$. Year dummy variables are not reported. 
The majority of the legislative production in U.S. states occurs during the regular legislative session. However, special sessions can be called when the legislative branch and the executive branch perceive urgent issues that require immediate action. The National Conference of State Legislatures explains that these special sessions may be called for a number of reasons. Court decisions, federal government actions, natural disasters, redistricting issues, and state economy issues can result in a special session. Additionally, limitations on the length or scope of both regular and special sessions, legislative and executive party control, and the political culture of the state can also affect the decision to call a special session. Other factors may influence a special session as well. There are no limits on the number of special sessions that can be called in a given year.

Previous research (Matsusaka 1995, 2004; Gerber 1996, 1999; Arceneaux 2002) and the preceding section in this paper find that the indirect effect of the voter initiative does affect policy outcomes and the production of legislation. This section examines the reasons that special sessions are called. If the availability of the voter initiative causes the state legislature to enact legislation to avoid potentially unfavorable voter initiatives, it seems possible that more special sessions would be called in states in which the voter initiative is available. Special sessions can be called for a wide variety of reasons. The threat of the voter initiative may influence the legislature's decision to call a special session. Special sessions may be called explicitly to deal with the threat of a voter initiative. However, it seems more likely that the threat of a voter initiative could serve as one of several reasons to call a special session. The voter initiative could provide the additional incentive required for the legislature to approve of a special session. 
Unfortunately previous research does not provide an example that can guide the process of estimating state special sessions. However, it is possible to control for some variables that could be responsible for special sessions. It seems reasonable to assume that many of the variables that affect the production of legislation could also affect special sessions. Population serves as a reasonable proxy for the demand of legislation. The log of population is included in the specification. The regular session length is also included. When regular sessions are longer, state legislators should be able to address more issues. Legislators may not have enough time to address important issues when the regular session is shorter. This analysis will also control for states that have a single subject clause and a clause requiring revenue bills to originate in the house chamber. While these seem to lead to a reduction in the number of bills passed in the regular session, it is difficult to asses the impact of these clauses on special sessions. While they may lead to more special sessions because they seem to make it more difficult to pass legislation, they could reduce the number of sessions because legislators know that the clauses will affect their ability to enact legislation if they do call a special session.

Some states allow both the legislature and the governor to call special sessions while other states relegate decisions concerning special sessions to the governor. ${ }^{19}$ A dummy variable is included to account for the states in which the governor is solely responsible for special sessions. Several states place limitations on the scope of legislature in the regular session. ${ }^{20} \mathrm{~A}$ dummy variable is also included to account for these states. Divided legislature seems to have an ambiguous affect on the decision to call a special session. A divided legislature could lead to a reduction in the number bills enacted in the regular session, leaving issues unresolved and

\footnotetext{
${ }^{19} 32$ states allow both the legislature and the governor to call a special session while 18 states restrict decisions on special sessions to the discretion of the governor.

${ }^{20}$ Six states limit the scope of legislation every other year. However, the majority of the limitations are so broad that they have little effect (National Conference of State Legislators).
} 
requiring a special session. However, divided legislatures may be less likely to agree to a special session because of political differences. A dummy variable that takes the value of one for states with a divided legislature is included. A variable is included to account for situations in which a unified legislature and an opposite party governor are involved. This should result in less cooperation between the two branches and may lead to a reduction in the number of special sessions.

Some variables are included to account for the political environment of the state. A dummy variable for republican governors is included to test if republican governors are less likely to call special sessions. The logged percentage of republicans and the percentage turnover from the previous year for both the house and senate are included to account for politics in the legislature. A variable is also included to check whether legislatures call more special sessions in order to deal with natural disasters. ${ }^{21}$ Finally, the impact of the voter initiative is examined with a dummy variable that takes the value of one when the state has the voter initiative process available. Once again, the data sources for this analysis are listed in the appendix.

The dependent variable is the number of special sessions called by a U.S. state in a calendar year. Descriptive statistics are presented in Table 5.1. The results are presented in Table 5.3. The analysis indicates that the voter initiative has a positive and significant effect on the number of special sessions called in a given year. This result is robust to different specifications of the model. States in which the voter initiative process is available had about 0.32 more special sessions from 1981 - 2001 than states in which the voter initiative process is unavailable.

The results in Table 5.3 display some other interesting results. It seems that states with higher populations call more special sessions. Longer regular legislative sessions lead to a

\footnotetext{
${ }^{21}$ The numbers of natural disasters as declared by FEMA are used in the analysis.
} 


\section{Table 5.3: Number of Special Sessions in U.S. States}

\begin{tabular}{|c|c|}
\hline Independent Variable & Coefficient Estimates \\
\hline Voter Initiative & $\begin{array}{c}0.3211 * * * \\
(.01053)\end{array}$ \\
\hline Population (log) & $\begin{array}{c}0.1651 * * * \\
(0.0553)\end{array}$ \\
\hline Session Length & $\begin{array}{c}-0.0036 * * * \\
(0.0009)\end{array}$ \\
\hline Bill Single Subject Clause & $\begin{array}{c}0.1502 \\
(0.1449)\end{array}$ \\
\hline Revenue Bill Origination Clause & $\begin{array}{c}-0.1525 \\
(0.1027)\end{array}$ \\
\hline Legislative Scope Limits & $\begin{array}{c}0.0355 * * \\
(0.1668)\end{array}$ \\
\hline Gubernatorial Control of Special Sessions & $\begin{array}{c}0.1221 \\
(0.1054) \\
\end{array}$ \\
\hline Divided Legislature & $\begin{array}{c}-0.0684 \\
(0.1363) \\
\end{array}$ \\
\hline Opposite Party Governor & $\begin{array}{l}-0.0975 \\
(0.1151)\end{array}$ \\
\hline Republican Governor & $\begin{array}{c}-0.1082 \\
(0.1036)\end{array}$ \\
\hline House Republicans (\% log) & $\begin{array}{c}0.2938 \\
(0.1864)\end{array}$ \\
\hline Senate Republicans $(\% \log )$ & $\begin{array}{c}-0.4480 * * * \\
(0.1627)\end{array}$ \\
\hline House Turnover (\%) & $\begin{array}{c}0.0188 * * * \\
(0.0062)\end{array}$ \\
\hline Senate Turnover $(\%)$ & $\begin{array}{c}0.0077 \\
(0.0057) \\
\end{array}$ \\
\hline Natural Disasters & $\begin{array}{c}0.0931 \\
(0.0622) \\
\end{array}$ \\
\hline Constant & $\begin{array}{c}-1.0054 \\
(0.9466)\end{array}$ \\
\hline Adjusted R-Squared & 0.1897 \\
\hline
\end{tabular}

Note: Dependent variable is the number of special sessions called in a calendar year in U.S. States during odd years from $1981-$ 2001 (due to the information available in the Book of States). Standard errors are noted in parenthesis. There are 460 observations. Asterisks indicate significance as follows: $* * *=1 \%, * *=5 \%, *=10 \%$. Year dummy variables are not reported.

reduction in the number of special sessions called. The longer time could increase the legislator's opportunity to resolve issues in the regular session. Additionally state senates with a higher percentage of republicans are less likely to call a special session while a more junior house is slightly more likely to call a special session. 


\subsection{The Governor's Veto}

Governors in 49 U.S. states possess some degree of veto power over the decisions that are made in the legislature. The veto is enacted by the governor when the legislature attempts to pass a policy that the governor views as unfavorable. Once again, the indirect effect of the voter initiative has been shown to significantly affect policy outcomes and legislative production (Matsusaka 1995, 2004; Gerber 1996, 1999; Arceneaux 2002). This section examines the reaction of the state governors to the increased legislative production due to the threat of the voter initiative.

Previous research can provide some insight into this discussion. Matsusaka (2004) and Gerber $(1996,1999)$ find that the voter initiative leads to policies that are preferred by the median voter. There are some reasons to believe that the state governor and the median voter may favor similar policies (Matsusaka 2005c). The governor is elected by a majority in a statewide election (Matsusaka 2005c). On the other hand, the legislature is chosen through district level elections. Previous studies find that the preferences of the state legislature may not be aligned with the median voter in the state (Gilligan and Matsusaka 2001, 2004; Bradbury and Crain 2001; Baqir 2002). However, the threat of the voter initiative may cause the legislature to enact legislation that is more aligned with the preferences of the state median voter. If the preferences of the governor are aligned with those of the state median voter, it seems reasonable to expect that the governor would prefer the legislation that occurs due to the indirect effect of the voter initiative. Additionally, voter initiatives are not subject to the governor's veto. If legislation is enacted in order to prevent the proposal of a voter initiative, the governor may not veto the legislation because voters could enact the policy through a voter initiative. Therefore, 
the expectation is that governors will be less likely to veto legislation in states in which the voter initiative is available.

In order to evaluate this hypothesis, this paper estimates state gubernatorial vetoes from 1981 - 2001. Numerous studies have examined the impact of the gubernatorial veto (Abrams and Dougan 1986; Holtz-Eakin 1988; Carter and Shap 1990; Alm and Evers 1991). They largely conclude that the immediate impact of the gubernatorial veto depends largely on the political parties of the governor and the legislature and the political climate in the state. This empirical specification attempts to control for these issues. Additionally, other variables are included to account for some of the differences between states.

The log of population is included to proxy the demand for legislation. The number of bills serves as an indicator of the activity level of the state legislature. It is expected that more bills will be vetoed when a legislature more actively attempts to pass legislation. Session length is also included as governors may veto more bills when the legislature has more time to enact legislation. Dummy variables are included to test the effects of states that have a single subject clause and a clause that requires a revenue bill to originate in the house chamber. Dummy variables are also included to account for governors that face a unified opposite party legislature and governors that face a divided legislature. The political party of the governor may affect the usage of the gubernatorial veto. A variable is included to account for republican governors. Finally, the impact of the voter initiative is examined with a dummy variable that takes the value of one when the state has the voter initiative process available.

The dependent variable is the number of vetoes exercised by the state governor during the regular legislative session. The descriptive statistics are presented in Table 5.1. Data sources are reported in the appendix. Results are presented in Table 5.4. The availability of the voter 
Table 5.4: Gubernatorial Vetoes in U.S. States

\begin{tabular}{|l|c|}
\hline \multicolumn{1}{|c|}{ Independent Variable } & Coefficient Estimates (standard errors in parenthesis) \\
\hline Voter Initiative & $\mathbf{- 1 3 . 8 7} * * *$ \\
& $\mathbf{( 4 . 0 5 )}$ \\
\hline Bills Enacted & $0.0719^{* * *}$ \\
& $(0.0059)$ \\
\hline Population (log) & $7.04 * * *$ \\
& $(2.16)$ \\
\hline Session Length & 0.0545 \\
& $(0.0354)$ \\
\hline Bill Single Subject Clause & $19.14 * * *$ \\
& $(5.46)$ \\
\hline Revenue Bill Origination Clause & $-15.32 * * *$ \\
& $(4.15)$ \\
\hline Divided Legislature & -8.40 \\
& $(5.25)$ \\
\hline Opposite Party Governor & 5.34 \\
& $(4.57)$ \\
\hline Republican Governor & $6.72 *$ \\
& $(4.00)$ \\
\hline Constant & \\
\hline Adjusted R-Squared & -128.50 \\
\hline
\end{tabular}

Note: Dependent variable is the number of gubernatorial vetoes in the calendar year in U.S. States during odd years from $1981-$ 2001 (due to the information available in the Book of States). Standard errors are noted in parenthesis. There are 460 observations. Asterisks indicate significance as follows: $* * *=1 \%, * *=5 \%, *=10 \%$. Year dummy variables are not reported.

initiative has a negative and significant effect on the use of the gubernatorial veto. This result is robust to different specifications of the model. Governors in voter initiative states are less likely to wield veto power. These results seem to agree with the original hypothesis. The threat of the voter initiative can persuade the legislature to enact policies that are better aligned with the preferences of the median voter. Since the preferences of the governor may be better aligned with the preferences of the median voter, the governor is less likely to veto legislation in states in which the voter initiative is available. Additionally, the governor may not veto legislation that is the result of the indirect effect of the voter initiative because voters can enact the measure through the voter initiative process. State governors cannot veto successful voter initiatives. 
The analysis reveals some other interesting results. A larger number of bills and a larger population both lead to greater usage of the gubernatorial veto. Single subject clauses for bills increase the number of vetoes enacted while clauses that require revenue bills to originate in the house chamber result in less usage of the gubernatorial veto. Finally, Republican governors seem a bit more likely to veto legislation.

\subsection{Conclusion}

This paper examines the impact of the voter initiative on legislative production in U.S. States. In theory, the threat of the voter initiative can cause the state legislature to preemptively enact legislation in order to avoid an unfavorable outcome from the passage of a voter initiative (Gerber, 1996, 1999). However, the voter initiative could also cause legislatures to avoid controversial decisions (Magleby 1984; Cronin 1989), leading to a decrease in the production of legislation.

The results in this paper show that the availability of the voter initiative leads to an increase in the production of legislation in U.S. states. The threat of the voter initiative does have a significant impact on the state legislature. Additionally, the signature requirement has significant effects on the behavior of the legislature in states where the voter initiative process is available. State legislatures in voter initiative states are less responsive to the threat of a voter initiative when the signature requirement is high. The number of bills enacted as the result of the indirect effect of the voter initiative declines as the signature requirement rises.

The paper also examines the number of special sessions that are called in U.S. states. The results conclude that states in which the voter initiative process is available are more likely 
to call special sessions. The threat of the voter initiative can persuade the legislatures in voter initiative states to call special sessions.

Finally, the use of the gubernatorial veto is examined for U.S. states. Previous research has found that the voter initiative leads to policy outcomes that are favored by the median voter (Gerber 1996, 1999; Matsusaka 2004). Additionally, the preferences of the governor are more likely to coincide with those of the median voter than those of the state legislature (Matsusaka 2005c). Therefore the governor may prefer the policies that are enacted due to the threat of the voter initiative. Additionally, governors may not veto legislation that is the result of the indirect effect of the voter initiative because voters can enact a voter initiative directly. Governors cannot veto a successful voter initiative. The results conclude that governors are less likely to exercise their veto power when the voter initiative is available. 


\section{Chapter 6}

\section{Summary and Conclusion}

As the voter initiative process has gained importance in the past few decades, scholars and journalists have responded with a renewed interest in the voter initiative process. The primary question surrounding the voter initiative process in the modern era resembles the debate from early in the twentieth century. Proponents of the voter initiative praise the voter initiative process as a method by which the voters can directly influence legislation and combat wealthy special interest group influence. Opponents believe that rich special interest groups are the primary beneficiary of the voter initiative process. Additionally, scholars have examined numerous other effects of the voter initiative process. While previous research has provided a great deal of insight into the effects of the voter initiative process, many issues surrounding the voter initiative process have yet to be resolved. This dissertation has addressed a few of these important issues.

The essays in this dissertation provide several important conclusions concerning the voter initiative process. First, the existence of the voter initiative process does not decrease the effect of interest groups on government spending. This seems reasonable as interest groups play a vital role in the voter initiative process. Second, the availability of the voter initiative process decreases the power of the state legislative branch and the state executive branch. Additional evidence suggests that the state legislative branch may sustain a greater loss in power relative to the state executive branch. Third, the state legislature is more active in voter initiative states when compared to states in which the voter initiative process is unavailable. The final two conclusions imply that politicians are forced to engage in legislative activities that they would 
have otherwise avoided in the absence of the voter initiative process. This could suggest that the availability of the voter initiative process may force the government to be more responsive to the preferences of the voters.

While the previous literature has contributed greatly to our understanding of the effects of the voter initiative process, many aspects of the process require further investigation. The relatively modest attention that the voter initiative process has received in comparison to the voting process in general has resulted in a number of important issues remaining unanswered. The remainder of this section discusses some of these issues.

Twenty six states have the voter initiative process at the state level while the other twenty four states do not. Research has yet to completely explain the rationale for the existence of the voter initiative in only half of the states in the U.S. The vast majority of voter initiative states adopted the process in the beginning of the $20^{\text {th }}$ century. Previous inquiries including Hofstadter (1955), Cronin (1989), and McMath (1993) describe the progressive movement of the era but do not agree on a specific reason for the adoption of the voter initiative process. Price (1975) argues that western states may have been able to gain access to the voter initiative process because their state political systems were new and less traditional than older states in the east.

The usage of the voter initiative process in states has varied greatly over time. This has also yet to be completely explained. The voter initiative process was used to a great extent in the first few decades of the $20^{\text {th }}$ century. However, usage declined from the 1930's to the 1960's. Following California's lead in 1978, the voter initiative process once again regained popularity. Speculation suggests that the Great Depression and World War II contributed to the decline in voter initiative use in the middle of the $20^{\text {th }}$ century while technology drove the increase in voter initiative usage toward the end of the $20^{\text {th }}$ century. While these explanations offer a plausible 
argument for the observed differences in the usage of the voter initiative process, further research may be able to identify other explanations as well. It would be interesting to examine the correlation between public satisfaction with the political process (perhaps through political polls) and the usage of the voter initiative process.

While recent literature has started to focus on the effects of the voter initiative process, a great deal of uncertainty continues to surround the transition between the time that a voter initiative is passed in an election and the implementation of the passed voter initiative. The legislature ultimately must enact a voter initiative, but the effect of the voter initiative can be altered through the process of implementation and the passage of subsequent legislation. Gerber, Lupia, McCubbins, and Kiewiet (2001) and Gerber, Lupia, and McCubbins (2004) find that issues that are likely to be passed through the voter initiative process are less likely to be enforced than issues that are resolved by the state legislature. This issue could be investigated further through the examination of the resulting laws that are enacted when a voter initiative is passed and the other laws that are enacted by the legislature at the time. It would be also be interesting to examine the effects of the voter initiative process on the internal organization of the state legislature. Legislators in voter initiative states must consider voter initiatives once they are approved on the ballot and the possibility of future voter initiatives. The existence of the voter initiative process may lead to additional employees, committees, and meetings in order to address the issues.

The effect of the voter initiative process on the rights of minorities has been an issue of contention for years. While the adoption of a voter initiative will obviously result in the approval of a policy that the majority prefers while a minority does not, some issues may deprive the civil rights of a particular minority group of the population. Several voter initiatives in the 
past (including the violation of the civil rights of blacks and Japanese early in the $20^{\text {th }}$ century) fall into the latter category. The issue of gay marriage provides a more recent example of voter initiative topics that target minority groups. While the possible trampling of minority rights has certainly been an issue in the democratic process in general, it deserves closer evaluation in the voter initiative process as the outcomes are determined directly by the voters.

Exit poll data may provide another area that could assist in the understanding of the players in the voter initiative process. Lupia (1994) used exit poll data to show that voters can use the interest groups who support and propose voter initiatives as information to help them to decide whether they personally support the voter initiative in question. He found that voters who knew the stance of the interest groups behind the voter initiatives were able to vote their true preferences even if they did not know the specific details about the voter initiatives on the ballot. Exit poll data could be used in the future to attempt to gain a greater understanding of the effects of the voter initiative on the characteristics of the voters involved in the process.

Another important future consideration involves the effects of the voter initiative process on the behavior of interest groups. The voter initiative process affords interest groups an additional method to use in order to accomplish their goals. Boehmke (2005) has found that this leads to more interest groups and more interest group activity in voter initiative states. This leads to several interesting questions involving the interest groups in voter initiative states. It would be informative to examine what happens to the interest groups that are formed in order to propose or fight a voter initiative through time. These groups may form for one specific voter initiative and disband once the issue is settled. On the other hand, a group may form for a specific voter initiative and then evolve into a group that fights for other issues. Additionally, it would be interesting to examine the individuals involved in the interest group activity that is the 
result of the voter initiative process. The newly formed interest groups could simply be comprised of individuals in other interest groups that want to bring a specific issue to the forefront. However, the voter initiative process could actually increase the number of individuals that are involved in interest groups. Both of these issues could have a large impact on the nature of the political environment in voter initiative states. Finally, it would be interesting to examine the spatial effects of the voter initiative process. If an issue is proposed in a voter initiative state and interest groups are formed (or old groups become more active), the activity may spill over into neighboring states. This activity may then take different forms depending on whether the neighboring state has the voter initiative process available.

In the future, the voter initiative process will continue to be used for different purposes as technological progress continues and new issues are faced. All current signs seem to suggest that direct democracy will continue to play a significant role in the political process in the future. Further research will be required in order build on our understanding of the voter initiative in the past and to help us understand the effects of the voter initiative in the years to come. 


\section{References}

Abrams, Burton A. and William R. Dougan. 1986. "The Effects of Constitutional Restraints on Government Spending." Public Choice. Volume 49, $101-116$.

Alexander, Herbert. 1991. Reform and Reality: The Financing of State and Local Campaigns. New York: Twentieth Century Fund.

Alm, James and Mark Evers. 1991. "The Item Veto and State Government Expenditures." Public Choice. Volume 68, $1-15$.

Ansolabehere, Stephen and Alan Gerber. 1994. "The Mismeasure of Campaign Spending: Evidence from the 1990 U.S. House Elections.” Journal of Politics. Volume 56, 1109 1118.

Arceneaux, Kevin. 2002. "Direct Democracy and the Link between Public Opinion and State Abortion Policy." State Politics and Policy Quarterly. Volume 2, 372 - 385.

Baqir, Reza. 2002. "Districting and Government Overspending." Journal of Political Economy, Volume 110 (6), 1318 - 1354.

Bergstrom, Theodore C. and Robert P. Goodman. 1973. "Private Demand for Public Goods." American Economic Review. 63, 280-296.

Besley, Timothy and Stephen Coate. 2003. "Issue Unbundling by Voter Initiatives.” Working Paper, London School of Economics.

Beyle, Thad. The Gubernatorial Campaign Finance Database. June 1, 2007. $<$ http://www.unc.edu/ beyle/index.html>

Black, Duncan. 1958. The Theory of Committees and Elections. Cambridge, MA. Cambridge University Press.

Boehmke, Frederick J. 2002. "The Effect of Direct Democracy on the Size and Diversity of State Interest Group Populations.” Journal of Politics. 3, 827-844.

Boehmke, Frederick J. 2005. The Indirect Effect of Direct Legislation. Columbus, OH. Ohio State University Press.

The Book of the States. 1980 - 2003. Volumes 23 - 35. Lexington, KY. The Council of State Governments.

Borcherding, Thomas. E. and Robert. T. Deacon. 1972. "The Demand for the Services of Non-Federal Governments." American Economic Review. 62, 891-901.

Bowen, H.R. 1943. "The Interpretation of Voting in the Allocation of Economic Resources." 
Quarterly Journal of Economics. 58, 27-48.

Bowler, Shaun and Todd Donovan. 1998. Demanding Choices: Opinion and Voting in Direct Democracy." Ann Arbor: University of Michigan Press.

Bowler, Shaun and Todd Donovan. 2004. "Measuring the Effect of Direct Democracy on State Policy: Not All Initiatives are Created Equal." State Politics and Policy Quarterly. Volume 4 (3), $345-363$.

Bowler, Shaun, Todd Donovan, Ken Fernandez, and David McCuan. 1998. "Contending Players and Strategies: Opposition Advantages in Initiative Campaigns." in Citizens as Legislators: Direct Democracy in the United States. Shaun Bowler, Todd Donovan, and Caroline J. Tolbert, eds. Columbus, OH. Ohio State University Press. 80-108.

Bradbury, John Charles and W. Mark Crain. 2001. "Legislative Organization and Government Spending: Cross Country Evidence." Journal of Public Economics. Volume 82, 309 325.

Broder, David S. 2000. Democracy Derailed: Initiative Campaigns and the Power of Money. New York, NY. Harcourt Brace.

Buchanan, James M. and Gordon Tullock. 1962. The Calculus of Consent: Logical Foundations of Constitutional Democracy. Ann Arbor, MI. University of Michigan Press.

Carter, John R. and David Shap. (1990. "Line Item Veto: Where is Thy Sting?" Journal of Economic Perspectives. Volume 4, $103-118$.

Crain, W. Mark. and Tollison, Robert D. 1982 "Team Production in Political Majorities." Micropolitics. Volume 2 (1), $111-121$.

Cronin, Thomas. 1989. Direct Democracy: The Politics of Initiative, Referendum, and Recall. Cambridge, MA: Harvard University Press.

Delli Carpini, Michael X. and Scott Keeter. 1996. What Americans Know About Politics and Why it Matters. New Haven, CT. Yale University Press.

Deno, Kevin T. Stephen L. Mehay. 1987. "Municipal Management Structure and Fiscal Performance: Do City Managers Make a Difference?" Southern Economic Journal. 53, $627-642$.

Downs, Anthony. 1957. An Economic Theory of Democracy. New York, NY. Harper and Row.

Ernst, Howard R. 2001. "The Historical Role of Narrow-Minded Interests." in Dangerous Democracy: The Battle Over Ballot Initiatives in America." Larry J. Sabato, Howard R. Ernst, and Bruce A. Larson, eds. Lanham, MD. Rowman and Littlefield. 1-25. 
Feenberg, Daniel R. and Harvey S. Rosen. 1985. "State Personal Income and Sales Taxes: 1977-1983. NBER Working Paper Series, Working Paper No. 1631. National Bureau of Economic Research, Cambridge, MA.

Gerber, Elisabeth R. 1996. "Legislative Response to the Threat of Popular Initiatives." American Journal of Political Science, Volume 40 (1), 99 - 128.

Gerber, Elisabeth R. 1999. The Populist Paradox: Interest Group Influence and the Promise of Direct Legislation. Princeton, NJ: Princeton Press.

Gerber, Elisabeth R. and Arthur Lupia. 1995. "Campaign Competition and Policy Responsiveness in Direct Legislation Elections.” Political Behavior. Volume 17 (2), 287 $-306$.

Gerber, Elisabeth R. and Simon Hug. 2001. "Legislative Response to Direct Legislation.” In Referendum Democracy, eds. M. Mendelsohn and A. Parkin. New York: Palgrave.

Gerber, Elisabeth R., Arthur Lupia, Matthew D. McCubbins, and D. Roderick Kiewiet. 2001. Stealing the Initiative: How State Government Responds to Direct Democracy. Upper Saddle River, NJ: Prentice Hall.

Gerber, Elisabeth R., Arthur Lupia, and Matthew D. McCubbins. 2004. "When Does Government Limit the Impact of Voter Initiatives? The Politics of Implementation and Enforcement." Journal of Politics. 66: 43 - 68.

Gierzynski, Anthony and David Breaux. 1991. "Money and Votes in State Legislative Elections.” Legislative Studies Quarterly. Volume 16, 203 - 217.

Gilligan, Thomas W. and Krehbiel, Keith. 1987. "Collectiove Decision-making and Standing Committees: An Informational Rationale for Restrictive Amendment Procedures." Journal of Law, Economics, and Organizations. Volume 3 (Fall), 287 - 335.

Gilligan, Thomas W. and John G. Matsusaka. 2001. "Fiscal Policy, Legislature Size, and Political Parties: Evidence from the First Half of the Twentieth Century." National Tax Journal, Volume 54, 383 - 401.

Gilligan, Thomas W. and John G. Matsusaka. 2004. "A Simple Theory of Redistricting with Applications to Voting Rights Law.” Working paper, University of Southern California.

Gramlich, E.M. 1968. "Alternative Federal Policies for Stimulation State and Local Expenditures: A Comparison of their Effects. National Tax Journal. 21, 119-129.

Hayek, F. A. 1945. "The Use of Knowledge in Society.” American Economic Review. 35, 519-530. 
Hofstadter, Richard. 1955. The Age of Reform: From Bryan to F.D.R. New York. Vintage Books. 1955

Hogan, Robert E. 1999. "Campaign Spending in State Legislative Primary Elections." State and Local Government Review. Volume 31, 214 - 220.

Hogan, Robert E. 2000. "The Costs of Representation in State Legislatures: Explaining Variations in Campaign Spending." Social Science Quarterly. Volume 81 (4), 941 - 956.

Hogan, Robert E. and Keith E. Hamm. 1998. "The Costs of Representation in State Legislatures: Variations in District-Level Campaign Spending." Pages 55 - 79 in Joel A. Thompson and Gary F. Moncrief, eds., Campaign Finance in State Legislative Elections. Washington D.C.: Congressional Quarterly Press.

Holcombe, Randall G. 1980. "An Empirical Test of the Median Voter Model.” Economic Inquiry. 18, 260-274.

Holcombe, Randall G. 1985. Public Finance and the Political Process. Carbondale, IL. Southern Illinois University Press.

Holcombe, Randall G. and Russell S. Sobel. 1995. "Empirical Evidence on the Publicness of State Legislative Activities." Public Choice. 83, 47-58.

Holtz-Eakin, Douglas. 1988. "The Line-Item Veto and Public Sector Budgets: Evidence from the States." Journal of Public Economics. Volume 36, 269 - 292.

Howell, William, Adler, Scott, Cameron, Charles, and Rieman, Charles. 2000. "Divided Government and the Legislative Productivity of Congress, 1945 - 1994." Legislative Studies Quarterly. Volume 25, 285-312.

Initiative and Referendum Institute at the University of Southern California. June 1, 2007. $<$ http://www.iandrinstitute.org/>

Inman, Robert P. 1987. “Testing Political Economy's 'as if' Proposition: Is the Median Income Voter Really Decisive?" Public Choice. 33, 45-65.

Kahn, Matthew E. 2002. "Demographic Change and the Demand for Environmental Regulation." Journal of Policy Analysis and Management. 21, 45-62.

Kahn, Matthew E. and John G. Matsusaka. 1997. "Demand for Environmental Goods: Evidence from Voting Patterns on California Initiatives." Journal of Law and Economics. 40, 137-173.

Kalt, Joseph P. and Mark A. Zupan. 1984. "Capture and Ideology in the Economic Theory of Politics.” American Economic Review. 74, 279-300. 
Kau, James B. and Paul H. Rubin. 1979. "Self Interest, Ideology, and Logrolling in Congressional Voting." Journal of Law and Economics. 22, 365-384.

Kelly, Sean Q. 1993. “Divided We Govern? A Reassessment.” Polity. Volume 25, 475 - 484.

Kessler, Anke S. 2005. "Representative Versus Direct Democracy: The Role of Information Asymmetries." Public Choice. 22, 9-38.

King, Kerry A. 2006. Essays on the Publicness of Education and the Effects of School Choice on Student Achievement. Proquest/IMI. PhD Dissertation, West Virginia University.

Kirchgässner, Gebhard and Anne Meyer Zu Himmern. 1997. "Expected Closeness and Turnout: An Empirical Analysis for the German General Elections, 1983 - 1994." Public Choice. Volume 91, 3 - 25.

Krehbiel, Keith. 1998. Pivotal Politics: A Theory of U.S. Lawmaking. Chicago, IL: University of Chicago Press.

Langbein, Laura. 2004. "Public School Music: Notes on the Public Provision of a Quasiprivate Good.” Public Choice. 121, 83-98.

Lott, Jr., John R. 2000. “A Simple Explanation for Why Campaign Expenditures are Increasing: The Government is Getting Bigger." Journal of Law and Economics. Volume 43.

Lupia, Arthur. 1994. "Shortcuts Versus Encyclopedias: Information and Voting Behavior in California Insurance Reform Elections." American Political Science Review. 88, pp. 6376.

Lupia, Arthur. 2001. "Dumber than Chimps? An Assessment of Direct Democracy Voters." in Dangerous Democracy? The Battle over Ballot Initiatives in America. Larry J. Sabato, Howard R. Ernst, and Bruce A. Larson, eds. Lanham, MD. Rowman \& Littlefield Publisher, 66-70.

Lupia, Arthur and Johnston, R. 2001. "Are Voters to Blame? Voter Competence and Elite Maneuvers in Public Referendums." in Referendum Democracy: Citizens, Elites, and Deliberation in Referendum Campaigns. Matthew Mendelsohn and Andrew Parkin, eds. Toronto. MacMillan/St. Martin's. 191-210.

Lupia, Arthur and John G. Matsusaka. 2004. "Direct Democracy: New Approaches to Old Questions." Annual Review of Political Science. 7, 463-482.

Magleby, David. 1984. Direct Legislation: Voting on Ballot Propositions in the United States. Baltimore, MD: Johns Hopkins University Press.

Malbin, Michael J. and Thomas L. Gais. 1998. The Day After the Reform: Sobering Campaign Finance Lessons from the American States. New York: Rockefeller Institute Press. 
Maskin, Eric and Jean Tirole. 2004. "The Politician and the Judge: Accountability in Government." American Economic Review. 94, 1034-1054.

Matsusaka, John G. 1992. "Economics of Direct Legislation.” Quarterly Journal of Economics, May 1992.

Matsusaka, John G. 1995. "Fiscal Effects of the Voter Initiative: Evidence from the Last 30 Years.” Journal of Political Economy. Volume 103, 619 - 650.

Matsusaka, John G. 2004. For the Many or the Few: The Initiative, Public Policy, and American Democracy. Chicago, IL. University of Chicago Press.

Matsusaka, John G. 2005a. "Direct Democracy Works.” Journal of Economic Perspectives. 19, 185-206.

Matsusaka, John G. 2005b. "The Eclipse of Legislators: Direct Democracy in the $21^{\text {st }}$ Century." Public Choice. 124, 157-177.

Matsusaka, John G. 2005c. "Direct Democracy and the Executive Branch.” Working paper, University of Southern California.

Matsusaka, John G. and Nolan M. McCarty. 2001. "Political Resource Allocation: Benefits and Costs of Voter Initiatives." Journal of Law, Economics, and Organization. Volume 17, $413-438$.

Mayhew, David R. 1974. Congress: The Electoral Connection. New Haven, CT: Yale University Press.

Mayhew, David R. 1991. Divided We Govern: Party Control, Lawmaking, and Investigations, 1946 - 1990. New Haven, CT: Yale University Press.

McCormick, Robert E. and Robert D. Tollison. 1981. Politicians, Legislation and the Economy. Boston, MA. Martinus Nijhoff.

McLennan, Andrew. 1998. "Consequences of the Condorcet Jury Theorem for Beneficial Information Aggregation by Rational Agents." American Political Science Review. 92, 413-418.

McMath, Robert C., Jr. 1993. American Populism: A Social History, 1877-1898. New York: Hill and Wang.

Moncrief, Gary F. 1992. "The Increase in Campaign Expenditures in State Legislative Elections: A Comparison of Four Northwestern States." Western Political Quarterly. Volume 45, $549-558$. 
Moncrief, Gary F. 1998. "Candidate Spending in State Legislative Races." In Campaign Finance in State Legislative Elections Joel A. Thompson and Gary F. Moncrief, eds. Washington D.C.: Congressional Quarterly Press.

Muth, J. 1961. "Rational Expectations and the Theory of Price Movements." Econometrica. Volume 29, $315-335$.

The National Center for Higher Education Management Systems, State Tax Effort - Effective Tax Rate. September 18, 2006. <http://www.higheredinfo.org/>

National Institute on Money in State Politics. June 1, 2007. < http://www.followthemoney.org/>

Palda, Filip. 1992. "The Determinants of Campaign Spending: The Role of the Government Jackpot.” Economic Inquiry. Volume 30, 627 - 638.

Peltzman, Sam. 1984. "Constituent Interest and Congressional Voting." Journal of Law and Economics. 27, 181-210.

Price, Charles M. 1975. "The Initiative: A Comparative State Analysis and Reassessment of a Western Phenomenon.” Western Political Quarterly. 28: 243-262.

Rogers, James R. 2002. "Free Riding in State Legislatures.” Public Choice. Volume 13 (1-2), 59 -76 .

Rogers, James R. 2005. “The Impact of Divided Government on Legislative Production.” Public Choice. Volume 123, $217-233$.

Romer, Thomas and Howard Rosenthal. 1979. "Bureaucrats versus Voters: On the Political Economy of Resource Allocation by Direct Democracy." Quarterly Journal of Economics. 93, pp. 563-587.

Schmidt, David. 1991. Citizen Lawmakers: The Ballot Initiative Revolution. Temple University Press.

Stardust Christian Academy: State Outline Maps. June 1, 2007. <http://www.geocities.com/Athens/Sparta/4692/StateOutlineMaps.html>

Statistical Abstract of the United States. June 1, 2007. $<$ http://www.census.gov/compendia/statab/past_years.html>

Turnbull, Geoffrey K. and Peter M. Mitias. 1995. "Which Median Voter?" Southern Economic Journal. 62, 183-191.

Weingast, Barry R., Kenneth A. Shepsle, and Christopher Johnsen. 1981. "The Political Economy of Benefits and Costs: A Neoclassical Approach to Distributive Politics." Journal of Political Economy. 89, pp. 642-664. 
Wilde, J.A. 1968. "The Expenditure Effects of Grant-in-aid Programs." National Tax Journal. $21,340-348$. 


\section{Appendix}

\section{Chapter 3: Data sources and variable definitions}

\begin{tabular}{|c|c|c|}
\hline Variable & Definition & Source \\
\hline $\begin{array}{l}\text { Total State Government } \\
\text { Expenditures }(S)\end{array}$ & Total state expenditures in millions of dollars & A \\
\hline Population $(N)$ & State population in thousands & A \\
\hline Income $\left(Y_{i}^{*}\right)$ & Median state income in dollars & A \\
\hline Population Density ( $D E N)$ & State population per square mile & $\mathrm{A}$ \\
\hline Median Age ( $A G E)$ & State median age & $\mathrm{B}$ \\
\hline$\%$ Non-white $(N W)$ & State percentage of population non-white & $\mathrm{A}$ \\
\hline $\begin{array}{l}\text { \# Local Governments } \\
(L O C A L)\end{array}$ & $\begin{array}{l}\text { State number of municipal and county governments per } \\
\text { square mile }\end{array}$ & $\mathrm{A}$ \\
\hline Pop. Growth Rate (CPOP) & Percent change in population from previous year & A \\
\hline Initiative $(I)$ & $=1$ for states with the voter initiative & $\mathrm{E}$ \\
\hline \multirow[t]{4}{*}{ Federal Grants $(F)$} & Federal grants to states in millions of dollars & A \\
\hline & State general sales and income tax revenue in millions & A \\
\hline & Average effective income and sales tax rate for 1980 & $\mathrm{C}$ \\
\hline & $\begin{array}{l}\text { Average effective income and sales tax rate for } 1990 \\
\text { (using estimates for 1992) and } 2000\end{array}$ & $\mathrm{D}$ \\
\hline
\end{tabular}

Sources:

A: Statistical Abstract of the U.S., U.S. Census Bureau

B: Census of Population, U.S. Census Bureau

C: Feenberg and Rosen (1985)

D: National Center for Higher Education Management Systems

E: Matsusaka (2004) 


\section{Appendix}

Chapter 4: Data sources and variable definitions.

\begin{tabular}{|c|c|c|}
\hline Variable & Definition & Source \\
\hline Legislative Dependent Variable & Total state district legislator election cycle spending per capita & A \\
\hline Voter Initiative & $=1$ if the voter initiative process is available in the state & B \\
\hline Signature Requirement & $=$ percentage signature requirement & B \\
\hline Number of Candidates & Total number of candidates in legislative district election & A \\
\hline Contribution Limits & $\begin{array}{l}=1 \text { if labor unions and corporations are prohibited from contributing to } \\
\text { legislative campaigns, PACs are limited }\end{array}$ & $\mathrm{C}$ \\
\hline Public Funding & $=1$ if public funding is available to all state legislative candidates & $\mathrm{C}$ \\
\hline Legislative Professionalism & Index by Squire (1992) and King (2000) on a scale of 0 to 1 & $\mathrm{D}$ \\
\hline $\begin{array}{l}\text { Per Capita State Expenditures } \\
\text { (thousands) }\end{array}$ & State expenditures per capita for year & $\mathrm{E}$ \\
\hline $\begin{array}{l}\text { Gubernatorial Dependent } \\
\text { Variable }\end{array}$ & Total election cycle gubernatorial spending per capita & F \\
\hline Per Capita Income (thousands) & State income per capita in thousands $(\$ 2000)$ & $\mathrm{E}$ \\
\hline $\begin{array}{l}\text { Per Capita State Expenditures } \\
\text { (thousands) }\end{array}$ & State expenditures per capita in thousands $(\$ 2000)$ & $\mathrm{E}$ \\
\hline Population & State population & $\mathrm{E}$ \\
\hline Split Control State Legislature & $=1$ if control of state legislative chambers is split by parties & G \\
\hline Maximum Consecutive Years & Maximum number of years governor can serve & $\mathrm{F}$ \\
\hline Length of Term & Term length of governor & F \\
\hline No Incumbent & $=1$ if there was not incumbent in the gubernatorial election & $\mathrm{H}$ \\
\hline Total Number of Candidates & Total number of candidates in the gubernatorial election & $\mathrm{H}$ \\
\hline Percent Difference Senate & $\begin{array}{l}\text { Percentage difference between republicans and democrats in the upper } \\
\text { chamber }\end{array}$ & $\mathrm{G}$ \\
\hline Percent Difference House & $\begin{array}{l}\text { Percentage difference between republicans and democrats in the lower } \\
\text { chamber }\end{array}$ & G \\
\hline General Incumbent & $=1$ if there is an incumbent in the gubernatorial general election & $\mathrm{H}$ \\
\hline General \# of Candidates & Number of candidates in the gubernatorial general election & $\mathrm{H}$ \\
\hline General Winning Margin & Percentage winning margin in the gubernatorial general election & $\mathrm{H}$ \\
\hline Republican Incumbent & $=1$ if there is an incumbent in the gubernatorial republican primary & $\mathrm{H}$ \\
\hline No Republican Challenger & $=1$ if there is no challenger in the gubernatorial republican primary & $\mathrm{H}$ \\
\hline Republican \# of Candidates & Number of candidates in the gubernatorial republican primary & $\mathrm{H}$ \\
\hline Republican Wining Margin & Percentage winning margin in the gubernatorial republican primary & $\mathrm{H}$ \\
\hline Democratic Incumbent & $=1$ if there is an incumbent in the gubernatorial democratic primary & $\mathrm{H}$ \\
\hline No Democratic Challenger & $=1$ if there is no challenger in the gubernatorial democratic primary & $\mathrm{H}$ \\
\hline Democratic \# of Candidates & Number of candidates in the gubernatorial democratic primary & $\mathrm{H}$ \\
\hline Democratic Wining Margin & Percentage winning margin in the gubernatorial democratic primary & $\mathrm{H}$ \\
\hline
\end{tabular}

Sources:
A: The National Institute on Money in State Politics
B: Initiative and Referendum Institute
C: National Conference of State Legislators
D: Squire (1992) and King (2000)
E: Statistical Abstract of the U.S., U.S. Census Bureau
F: The Book of the States
G: World Almanac and Book of Facts
H: Congressional Quarterly's Guide to U.S. Elections 


\section{Appendix}

\section{Chapter 5: Data sources and variable definitions}

\begin{tabular}{|c|c|c|}
\hline Variable & Definition & Source \\
\hline Number of Bills Enacted & $\begin{array}{l}\text { Number of bills enacted in U.S. state regular legislative } \\
\text { session }\end{array}$ & A \\
\hline Number of Special Sessions & Number of special sessions called in U.S. states & A \\
\hline $\begin{array}{l}\text { Number of Gubernatorial } \\
\text { Vetoes }\end{array}$ & $\begin{array}{l}\text { Number of gubernatorial vetoes U.S. state regular legislative } \\
\text { session }\end{array}$ & A \\
\hline Initiative & $=1$ for states in which the voter initiative is available & $\mathrm{B}$ \\
\hline Signature Requirement & $=\%$ signature requirement for initiative states & B \\
\hline Population (log) & Log of the population (in 1000's) & $\mathrm{C}$ \\
\hline Session Length & Number of legislative work days in the regular session & A \\
\hline Bill Single Subject Clause & $=1$ for states that restrict bills to a single subject & $\mathrm{D}$ \\
\hline $\begin{array}{l}\text { Revenue Bill Origination } \\
\text { Clause }\end{array}$ & $\begin{array}{l}=1 \text { for states in which revenue bills must originate in the } \\
\text { house chamber }\end{array}$ & $\mathrm{D}$ \\
\hline Divided Legislature & $\begin{array}{l}=1 \text { for states in which legislative chambers have opposing } \\
\text { majority parties }\end{array}$ & $\mathrm{A}$ \\
\hline Opposite Party Governor & $\begin{array}{l}=1 \text { for states in which a unified legislature face an opposite } \\
\text { party governor }\end{array}$ & A \\
\hline Republican Governor & $=1$ for states with a republican governor & A \\
\hline House Republicans (\% log) & Log of the percentage of republicans in lower chamber & A \\
\hline Senate Republicans $(\% \log )$ & Log of the percentage of republicans in upper chamber & A \\
\hline House Turnover (\%) & $\begin{array}{l}\text { Percentage newly elected legislator from previous years lower } \\
\text { chamber election }\end{array}$ & A \\
\hline Senate Turnover (\%) & $\begin{array}{l}\text { Percentage newly elected legislator from previous years upper } \\
\text { chamber election }\end{array}$ & A \\
\hline House Standing Committees & Number of standing committees in the lower chamber & A \\
\hline Senate Standing Committees & Number of standing committees in the upper chamber & $\bar{A}$ \\
\hline Joint Standing Committees & Number of joint standing committees & A \\
\hline Number of House Legislators & Number of legislators in the lower chamber & A \\
\hline Number of Senate Legislators & Number of legislators in the upper chamber & $\bar{A}$ \\
\hline House Staff & Average staff allocated to lower chamber legislators & A \\
\hline Senate Staff & Average staff allocated to upper chamber legislators & A \\
\hline Salary (thousands) & State legislator salary in thousands & A \\
\hline Legislative Scope Limits & $\begin{array}{l}=1 \text { for states that limit the scope of legislative regular } \\
\text { sessions }\end{array}$ & $\mathrm{D}$ \\
\hline $\begin{array}{l}\text { Gubernatorial Control of } \\
\text { Special Sessions }\end{array}$ & $\begin{array}{l}=1 \text { if only state governors have authority to call special } \\
\text { sessions }\end{array}$ & $\mathrm{D}$ \\
\hline Natural Disasters & Number of natural disasters in state as defined by FEMA & $\mathrm{E}$ \\
\hline
\end{tabular}

Sources:
A: The Book of the States
B: Initiative and Referendum Institute
C: Statistical Abstract of the U.S., U.S. Census Bureau
D: National Conference of State Legislators
E: FEMA 